\title{
Wound Healing Activities of Hydromethanolic Crude Extract and Solvent Fractions of Bersama abyssinica Leaves in Mice
}

\author{
Solome Melkamu Taddese, ${ }^{1}$ Tiruzer Bekele Gurji, ${ }^{2}$ Mohammedbrhan Abdulwuhab, ${ }^{3}$ \\ and Tezera Jemere Aragaw $\mathbb{1}^{3}$ \\ ${ }^{1}$ Debre Tabor Health Science College, Debre Tabor, Ethiopia \\ ${ }^{2}$ Department of Pathology, College of Medicine and Health Sciences, University of Gondar, Gondar, Ethiopia \\ ${ }^{3}$ Department of Pharmacology, College of Medicine and Health Sciences, University of Gondar, Gondar, Ethiopia
}

Correspondence should be addressed to Tezera Jemere Aragaw; tezeraadis1982@gmail.com

Received 25 March 2021; Revised 1 June 2021; Accepted 7 July 2021; Published 15 July 2021

Academic Editor: Riaz Ullah

Copyright (c) 2021 Solome Melkamu Taddese et al. This is an open access article distributed under the Creative Commons Attribution License, which permits unrestricted use, distribution, and reproduction in any medium, provided the original work is properly cited.

\begin{abstract}
Background. Bersama abyssinica leaves are traditionally used for management of wounds in several communities of Ethiopia, despite no scientifically approved studies done on wound healing. Our study planned to work out the wound healing effects of B. abyssinica leaves extract in mice. Methods. B. abyssinica leaves were extracted with $80 \%$ hydromethanol and fractioned with chloroform, hexane, and water. The acute dermal toxicity of the crude extract was evaluated in mice. The crude extract formulated at $5 \%$ and $10 \% \mathrm{w} / \mathrm{w}$ ointment was investigated in excision, incision, and burn wound models and solvent fractions in the excision model using simple ointment (negative control) and nitrofurazone $0.2 \% \mathrm{w} / \mathrm{v}$ (positive control). We evaluated histopathological analysis, wound contraction rate, complete epithelialization period, and skin durability. One-way ANOVA followed by the post hoc Tukey HSD test with IBM SPSS software version 23.0 was used for data analysis, and $p<0.05$ was considered statistically significant. Results. Hydromethanolic crude extract produced 5\% (99.5\%) and 10\% (100\%) wound contraction on the $16^{\text {th }}$ day of the treatment and 5\% (18.8) and 10\% (28.2) percent reduction in the epithelization period on the excision wound healing model. Hydromethanolic crude extract produced 5\% (47.5) and 10\% (61.17) percent durability on the incision wound healing model. Hydromethanolic crude extract produced 5\% (99.82\%) and $10 \%(100 \%)$ wound contraction on the $20^{\text {th }}$ day of treatment and $5 \%$ $(13 \%)$ and $10 \%(21.7 \%)$ reduction in the epithelization period on the burn wound healing model. The chloroform fraction produced 5\% (90.17\%) and 10\% (91.01\%), hexane fraction produced 5\% (85.81\%) and 10\% (86.78\%), and aqueous fraction produced $5 \%(99.17 \%)$ and $10 \%(99.38 \%)$ wound contraction on the $14^{\text {th }}$ day of the treatment and $5 \%(18.8)$ and $10 \%(28.2)$ percent reduction in the epithelization period on the excision wound healing model. Both hydromethanolic crude extract and solvent fractions at $5 \%$ and $10 \%(\mathrm{w} / \mathrm{w})$ were significant $(p<0.001)$ compared with negative control. Conclusion. The results of this study showed that both $5 \% \mathrm{w} / \mathrm{w}$ and $10 \% \mathrm{w} / \mathrm{w}$ of $80 \%$ hydromethanolic crude extract and solvent fractions of B. abyssinica leaves have wound healing effects.
\end{abstract}

\section{Introduction}

Wound is any disruption of the skin associated with microbial, physical, and chemical agents [1]. It is associated with morbidity, disability, socioeconomic crisis, and mortality [2]. Wound management is maintaining a warm, moist, nontoxic environment that supports natural wound healing [3]. Traditional medicine is an accepted, effective, easily available, and affordable treatment by applying knowledge, which incorporate mineral, animal, and plant based medicine to treat, diagnose, and maintain wellbeing [4-7]. Traditionally used medicinal plants have wound healing activity due to phytoconstituents with mechanism of analgesic proliferative, antioxidant, anti-inflammatory, and 
antimicrobial effects, which are crucial for management of wounds [8].

B. abyssinica Fresen is a shrub approximately 6 meters in height, which is evergreen and common in some African countries including Ethiopia [9]. Fruits powder of B. abyssinica mixed with butter has been used to treat eczema [10]. Leaves and roots are used for management of hypertension and cough [11]. Leaves decoction as tea accustomed for Ascaris and diarrhea [12-15]. Fresh Shoot tip chewed and swallowed for management of Stomachache and squeezed juice applied on the wound [16]. Stem bark taken orally to treat tonsillitis [17]. Warm leaves hold on affected area for rheumatics [18]. Buds were taken orally to manage snake bite [19]. Leaves, stems, and roots decoction were used for malaria and taeniafuge, stem barks were applied topically for snake bite, and fresh roots were boiled in water and consumed orally for febrile illness, bronchitis, and cancer $[20,21]$. Roots and leaves decoction drunk with milk for rabies [13]. In Ethiopia, leafy-stem tips were squeezed and creamed on wound [22]. Leaves, stems, and roots decoction were applied on wound [23]. Leaves, roots, barks, and stems decoction were applied on wound [24]. Dry leaves were crushed or burned and mixed with butter for skin infection $[25,26]$. Seed powders were applied on wound and skin burn [27].

In vitro hydromethanolic and ester leaf extract of B. abyssinica exhibited higher activity against Klebsiella pneumonia, Staphylococcus aureus, Escherichia coli, and Salmonella typhosa [9]. Aqueous extract of stem bark of this plant had bactericidal activity against multiresistant strains of Staphylococcus aureus [28]. Leaf, stem bark, and root bark hydromethanolic extracts of $B$. abyssinica had higher antibacterial activities against two fast growing bacteria like M. madagascariense and $M$. indicus pranii at 0.039 and $0.78 \mathrm{mg} / \mathrm{mL}$, respectively [29]. Hydromethanolic stem bark crude extract of $B$. abyssinica possesses much higher antibacterial activity against Escherichia coli, Staphylococcus aureus, Klebsiella pneumonia, Bacillus subtilis, and Pseudomonas aeruginosa [30].

Hydromethanolic leaves extract of this plant had significant activity in scavenging of free radical, and 50 percent inhibitory concentration is $7.5 \mu \mathrm{g} / \mathrm{ml}$ [31]. Aqueous and hydroethanolic leaf extract possesses an antifungal activity with maximum effect of hydroethanolic extracts (minimum inhibitory concentration $=0.781 \mathrm{mgml}^{-1}$ and 50 percent inhibitory concentration is $0.08 \mathrm{mgml}^{-1}$ ) [32].

Phytochemical screening of $B$. abyssinica leaves extract revealed the presence of coumarins, terpenoids, saponins, polysterols, anthraquinones, triterpenes, tannins, phenols, steroids, flavonoids, glycosides, and alkaloids, whereas anthraquinones, saponins, and terpenoids were highly concentrated in methanolic extract $[9,33-37]$.

\section{Rationale of the Study}

B. abyssinica is utilized as wound healing agent in several communities of Ethiopia. It has been scientifically investigated for wound healing efficacy in vitro, but not in vivo. In vivo evaluation of this plant is also important to suggest safety and efficacy for continuous use in the community and can be a starting point for scientific communities to undergo further investigation for the development of effective as well as safe drug used for wound healing.

\section{Materials and Methods}

3.1. Drugs and Chemicals. Drugs and chemicals like Wool fat (Lab tech chemicals), hard paraffin (Lab tech chemicals), white petrolatum (Lab tech chemicals), cetostearyl alcohol (Lab tech chemicals), methanol absolute (Sisco Research lab pvt. ltd), chloroform (Carlo Erba reagents), hexane (Pentokey Organy India ltd), distilled water, nitrofurazone skin ointment $0.2 \%$ (Shanghai general pharmaceutical), ketamine hydrochloride injection USP(India), diazepam injection (Gland pharm limited, India), 70\% alcohol (Yilmana chemical production), normal saline (IV infusion BP Medsol pharmaceuticals), $10 \%$ formalin solution were procured from supplier and used.

\subsection{Plant Material Collection and Preparation. Bersama} abyssinica leaves were collected near Debre Tabor town (Alem Saga), at a latitude and longitude of $11^{\circ} 51^{\prime} \mathrm{N}, 38^{\circ} 1^{\prime} \mathrm{E}$ and 2706 meters above sea level on January 11, 2020. Specimen of B. abyssinica was identified taxonomically by a Botanist at the Department of Biology, College of Natural and Computational Science, University of Gondar, Gondar, Ethiopia, and registered with a reference number of $001 S M T / 2020$.

3.3. Experimental Animals. A total of 126 healthy adult swiss albino mice of weight $25-35 \mathrm{~g}$ and age 6-8 weeks of either sex for the actual experiment and 10 healthy female adult swiss albino mice for determining acute dermal toxicity test that were inbred at the Animal House of Department of Pharmacology, School of Pharmacy, College of medicine and Health Sciences, University of Gondar, Gondar, Ethiopia, were used. Mice were kept (five mice/cage) in clean polyethylene plastic cages with a wire mesh top containing a hygienic bed of course sawdust (regularly changed every 3 days) and retained in a well-ventilated room $24-25^{\circ} \mathrm{C}$, $50-60 \%$ humidity and a light-dark cycle of 12 hours with free delivery of standard pellet diet purchased from local suppliers and clean potable tape water. Then, the mice were acclimatized with the test environment for a week before the initiation of the experiment. The care and handling of mice were performed with globally accepted standard laboratory protocols and guidelines [38, 39]. And research was performed as per the agreement of the ethical clearance document Ref. No SoP4/153/12.

3.4. Preparation of the Hydromethanolic Crude Extract. To obviate contaminants and debris leaves, they were washed with water and shade-dried at room temperature and coarsely powdered with a hand compression to maximize penetration of extracting solvents. Powder material of plant was packed in tightly closed container until 
extraction. A coarsely powdered 1000 gm leaves of Bersama abyssinica were macerated in 6 liters of $80 \%$ hydromethanolic solution in Erlenmeyer flasks for 3 days with frequent shaking in between. After 3 days of maceration, extraction was performed using thick layers of 40 mesh gauze and filtered with Whatman paper No. 1. The residue was remacerated for 3 days two times using similar volume of $80 \%$ hydromethanolic solution to induce maximum yield. The filtrate was frozen overnight using deep-freeze and freeze-dried in a lyophilizer at $-50^{\circ} \mathrm{C}$ to eliminate water. The proportion yield of extract was determined and stored in a refrigerator at $4^{\circ} \mathrm{C}$ up to ointment formulation and solvent fractionation [40].

$$
\text { Percent yield }=\frac{\text { weight } \text { of the extract }}{\text { weight of the plant material }} \times 100 \text {. }
$$

\subsection{Solvent Fractionation of Hydromethanolic Crude Extract.} Hydromethanolic crude extract of Bersama abyssinica leaves was processed for further fractionation using water, chloroform, and hexane. $420 \mathrm{ml}$ of water was added to 70 gram hydromethanol in a separatory funnel. Then, equal volume of hexane was added thereto. After being gently shaken, the extract was allowed to settle and separated into two distinct layers according to their density. The upper hexane layer was collected, and thus identical procedure was repeated thrice. After the gathering of hexane fraction of the extract, the water portion was fractionated with chloroform 3 times with the same procedure of hexane, and so, the underside chloroform layer was collected, and finally, aqueous fraction was collected. The filtrates of chloroform and hexane fractions were concentrated by rotary evaporator and dried by dry oven at $40^{\circ} \mathrm{C}$. The aqueous fraction was frozen in refrigerator overnight and was dried with lyophilizer. The proportion yield was calculated and stored at $4^{\circ} \mathrm{C}$ until ointment formulation [40].

3.6. Ointment Formulation. Simple ointment and medicated ointments of $80 \%$ hydromethanolic crude extract, chloroform, hexane, and aqueous fractions were prepared per British Pharmacopeia [41].

Simple ointment base $300 \mathrm{gm}$ was prepared by placing $15 \mathrm{gm}$ of hard paraffin in a beaker and melted on electrical heater. Then, $15 \mathrm{gm}$ of Cetostearyl alcohol, $255 \mathrm{gm}$ of white petrolatum, and $15 \mathrm{gm}$ of wool fat were added in descending order of their temperature, respectively. All the ingredients were melted over electrical heater with constant stirring until they became homogeneous. Then, the mixture was removed from heat source and stirred until being cool. All ointments were prepared by levigation on the surface of the ointment slab to formulate ointment of uniform consistency and smooth texture. For negative control, $100 \mathrm{gm}$ of simple ointment base was prepared without active ingredient. Finally, hydromethanolic crude extract and solvent fractions ointment and simple ointment base were transferred to a clean closed container for topical application during the experiment [42] (see Table 1).
TABLe 1: Simple ointment formula [42].

\begin{tabular}{lcc}
\hline Ingredients & $\begin{array}{c}\text { Master formula (MF) } \\
(\mathrm{g})\end{array}$ & $\begin{array}{c}\text { Reduced formula (RF) } \\
(\mathrm{g})\end{array}$ \\
\hline Wool fat & 50 & 15 \\
Hard paraffin & 50 & 15 \\
$\begin{array}{l}\text { Cetostearyl } \\
\text { alcohol }\end{array}$ & 50 & 15 \\
$\begin{array}{l}\text { White } \\
\text { petrolatum }\end{array}$ & 850 & \\
Total & 1000 & 255 \\
\hline
\end{tabular}

3.7. Acute Toxicity Study. Acute oral toxicity was previously done in mice. The findings of this study showed that a limited dose of $2000 \mathrm{mg} / \mathrm{kg}$ was safe, and a median lethal dose $\left(\mathrm{LD}_{50}\right)$ of the extract was greater than $2000 \mathrm{mg} / \mathrm{kg}$ $[40,43]$. Acute dermal toxicity test of $80 \%$ hydromethanolic crude extract of Bersama abyssinica was performed in accordance with OECD guideline 425 with slight modification [44]. Ten healthy Swiss albino female mice showing normal skin texture were used. Mice were grouped into two, with five mice for control and five mice for test group. 24 hours before the study, $10 \%$ of surface fur of test mouse was removed with scissors from the dorsal area of the trunk. Initially sighting study was performed on one mouse to evaluate the starting dose by applying $2000 \mathrm{mg} / \mathrm{kg}$ of the ten percent formulation of the hydromethanolic crude extract uniformly over the shaved area and covered with surgical gauze and a nonocclusive bandage for 24 hours. During the exposure period, mouse was caged individually. At the end of the exposure period, residual test substance was washed out by water. Irritation or death was not observed within 24 hours. Then, the remaining four mice from each group were tested on the following day with limited test dose of $2000 \mathrm{mg} / \mathrm{kg}$ of $10 \%$ ointment formulation of the extract and observed for 24 hours. At the moment, mice were observed for development of any adverse skin reactions immediately after dosing, for half an hour, periodically during the first 24 hours, with special attention given during the first four hours, and daily for a total of 14 days [45].

3.8. Grouping and Dosing of Experimental Animals. Hydromethanolic crude extract was evaluated with excision, incision, and burn wound healing models, while solvent fractions were evaluated with excision wound healing model only. In excision and burn wound models, four groups of mice containing six mice in each group were used. Group-I was treated with hydromethanolic crude extract $5 \% \mathrm{w} / \mathrm{w}$ ointment, group-II treated with hydromethanolic crude extract $10 \% \mathrm{w} / \mathrm{w}$ ointment, group-III treated with nitrofurazone $0.2 \% \mathrm{w} / \mathrm{v}$ ointment (positive control), and groupIV treated with simple ointment (negative control). The identical grouping and dosing of mice were also used for incision wound healing model except addition of fifth group for untreated group [46].

For evaluation of solvent fractions (aqueous, chloroform, and hexane) in excision wound healing model, eight groups of mice containing six mice in each group were used. 
Group-I was treated with aqueous fraction $5 \% \mathrm{w} / \mathrm{w}$ ointment, group-II treated with aqueous fraction $10 \% \mathrm{w} / \mathrm{w}$ aqueous ointment, group-III treated with chloroform fraction 5\% w/w ointment, group-IV treated with chloroform fraction $10 \% \mathrm{w} / \mathrm{w}$ chloroform fraction ointment, group- $\mathrm{V}$ treated with hexane fraction $5 \% \mathrm{w} / \mathrm{w}$ ointment, group-VI treated with hexane fraction $10 \% \mathrm{w} / \mathrm{w}$ ointment, group-VII treated with nitrofurazone $0.2 \% \mathrm{w} / \mathrm{v}$ ointment (positive control), and group-VIII treated with simple ointment (negative control) [47].

3.9. Circular Excision Wound Model. For wounding purpose, the mice were anesthetized with intraperitoneal (IP) injection of ketamine + diazepam $(100 / 5 \mathrm{mg} / \mathrm{kg})$ [48]. Wound area was cleaned with $70 \%$ denatured hydroethanol, and also the dorsal furs of the mice were removed with a pair of scissors. Then, the estimated wound area was marked with thin permanent marker, and a full thickness excision wound around $300 \mathrm{~mm}^{2}$ was excised using forceps and small sharp sterilized pair of scissors to each mouse (Figure 1). Bleeding of wound was stopped by blotting the wound with cotton swab soaked with normal saline and left open. After recovery, each mouse was returned back to its cage and thought to be day-0 wounding day. Starting from day one, the wounded area was treated daily as described under dosing section until the wound of test groups completely healed. The wound healing activity of hydromethanolic crude extract and solvent fractions was assessed by period of epithelialization, percentage of wound contraction, and histological studies [45].

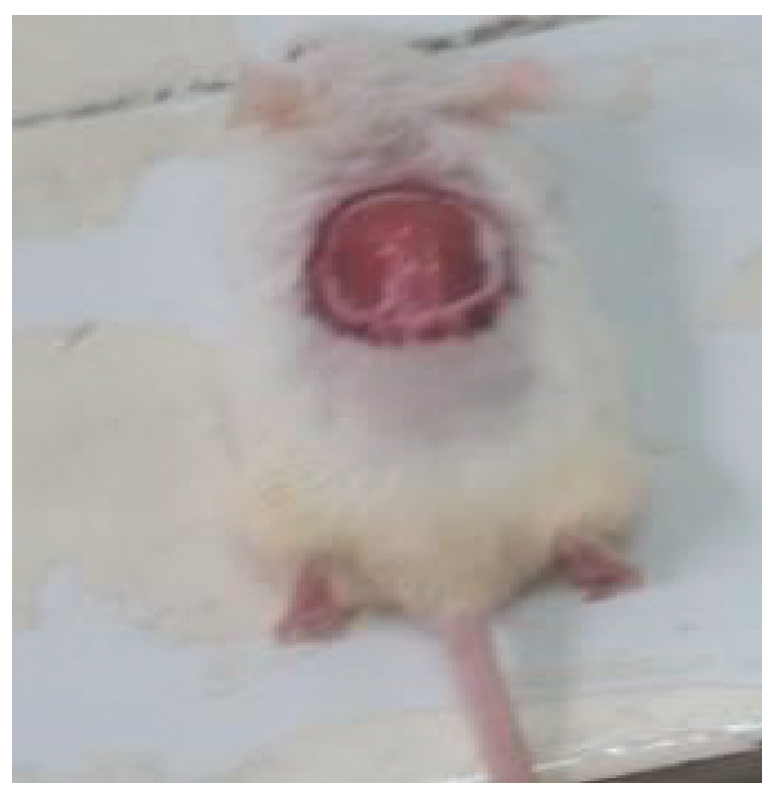

Figure 1: Photograph of circular excision wound on day 0.

\subsection{Wound Healing Parameters}

3.10.1. Wound Contraction. Wound contraction was evaluated by measuring wound areas using transparency paper and permanent marker. The measured area was important to calculate percentage of wound contraction and taken initial size of the wound, $300 \mathrm{~mm}^{2}$ as $100 \%$ with the following formula [49]:

$$
\% \text { wound contraction }=\frac{\text { initial } \text { wound size }- \text { wound size on day } n}{\text { initial wound size }} \times 100 \text {, }
$$

where $n=$ the days where measurement was taken $\left(2^{\text {nd }}, 4^{\text {th }}\right.$, and so forth).

3.10.2. Epithelization Period. Epithelization period was resolute by the number of days required for declension of the dead tissue remnants with none residual lesion [50].

3.11. Histopathological Analysis. Histopathological analysis was performed blindly by a pathologist. The skin specimens from each group were collected at the $18^{\text {th }}$ postwounding day of the experiment after the mice are sacrificed by overdose of anesthesia. Samples were fixed in $10 \%$ buffered formalin, processed, and blocked with paraffin and stained with hematoxylin and eosin. The tissues were examined by microscope and graded subjectively as mild $(+)$, moderate $(++)$, and severe $(+++)$ for epidermal or dermal remodeling, reepithelialization; fibroblast proliferation, mononuclear, and/or polymorphonuclear cells and collagen depositions in dermis were analyzed $[49,50]$.
3.12. Linear Incision Wound Model. The mice were anesthetized and shaved like circular excision wounds. Then, $3 \mathrm{~cm}$ long longitudinal paravertebral incision was made through the skin and subcutaneous tissue. The parted skin was stitched by nonabsorbable surgical thread and a curved needle at the intervals of $1 \mathrm{~cm}$ (Figure 2). After 24 hours of wound creation (on day-1), mice were treated as described under dosing section. The sutures were removed on day-9, and strength of the healed wound was measured on day-10 by continuous and constant water flow technique $[45,49]$.

3.13. Measurement of Tensile Strength. Mice were anesthetized and secured to the table. Two forceps were firmly applied $3 \mathrm{~mm}$ away from the edge of wound facing one another on opposite side of the incision wound. One among the forceps was fixed on stands, while the opposite was tied with rope to empty bottle, on which weight was placed. Water was allowed to flow continuously and slowly from IV bag filled with $1000 \mathrm{ml} \mathrm{H}_{2} \mathrm{O}$ into the container (Figure 3). The water flow was stopped immediately, just the wound 


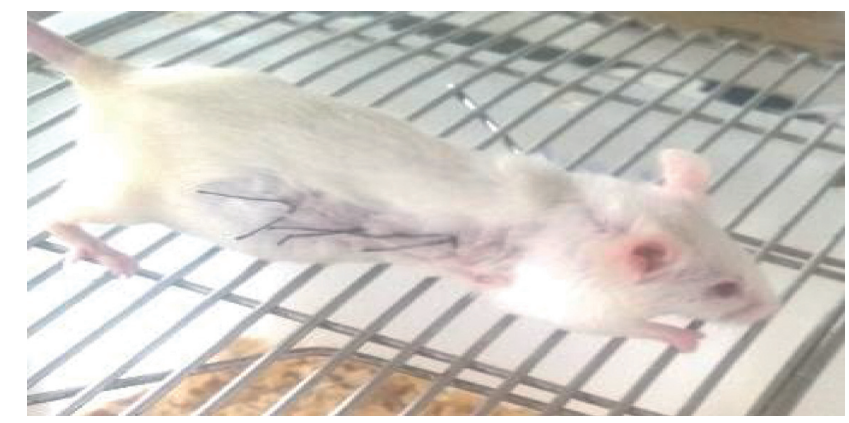

FIgURe 2: Photograph of incision wound on day 0.
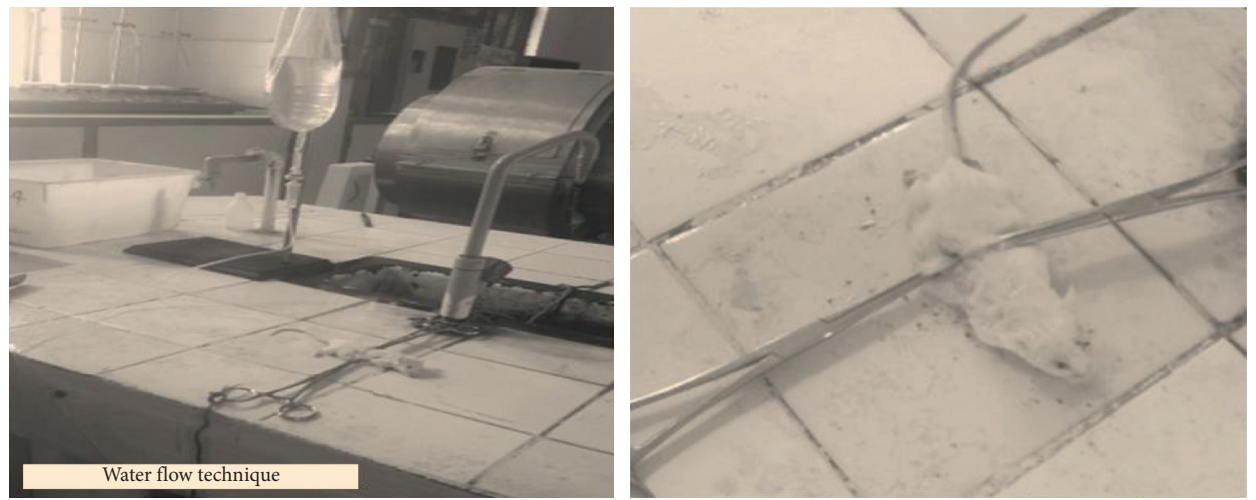

FIgURE 3: Photograph of the measurement of tensile strength by using water flow technique.

unfolded and therefore, the volume of water collected in the container (approximately equal to its weight) was recorded as tensile strength $[45,49]$.
Percent of durability was calculated using the subsequent formula:

$$
\begin{gathered}
\text { percent tensile strength }\left(\text { TS) of the extract }=\frac{\text { TS extract }- \text { TS so }}{\text { TS so }} \times 100,\right. \\
\text { percent tensile strength of the reference }=\frac{\text { TS reference }- \text { TS so }}{\text { TS so }} \times 100, \\
\text { percent tensile strength of simple ointment }=\frac{\text { TS So }- \text { TS lu }}{\text { TS lu }} \times 100,
\end{gathered}
$$

where so $=$ simple ointment and $\mathrm{Lu}=$ left untreated [50].

3.14. Burn Wound Model. Mice were divided randomly into four groups of six mice in each group, then anesthetized, and shaved like excision wound model. Following this, partial thickness burn wound was created by pouring hot molten waxes at $80^{\circ} \mathrm{C}$ into a metal cylinder of $300 \mathrm{~mm}^{2}$ circular opening placed on the shaved area of the mice and stayed until wax got solidified for 10-12 minutes. On solidification of wax, the metal cylinder with wax that adheres to the skin was removed (Figure 4). After recovery, mice were returned to their cage and treated as described under dosing section. Wound healing parameters like period of epithelialization, percentage of wound contraction, and histological studies were assessed [51].

3.15. Statistical Analysis. The results obtained from the experiments were expressed as mean \pm SEM. The result was statistically analyzed using one-way ANOVA followed by post hoc Tukey tests with SPSS version 23.0 software, and $p<0.05$ was considered as statistically significant. 


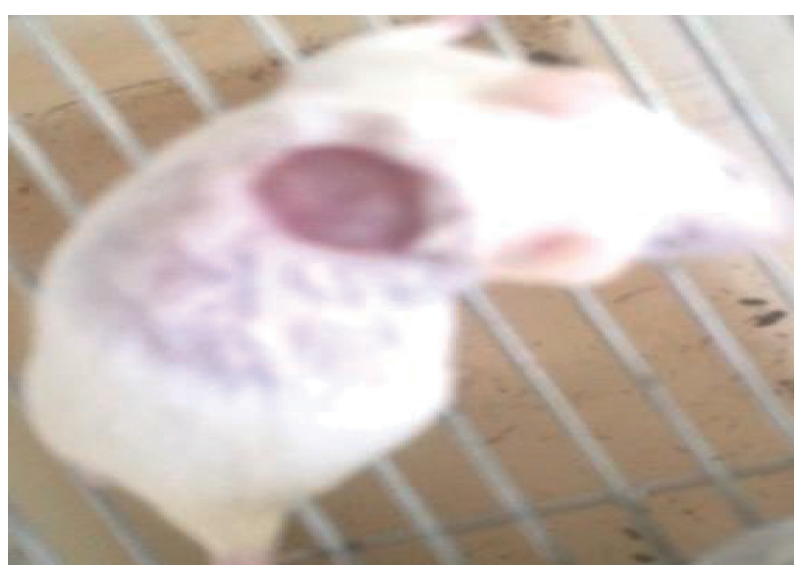

FIGURE 4: Circular burn wound on day 0 .

\section{Result}

4.1. Yield of Crude Extract and Solvent Fractions. High yield was obtained from aqueous fraction $(64.3 \%)$, and lower yield was obtained from $n$-hexane fraction (3.6\%) (see Table 2).

4.2. Acute Dermal Toxicity. The acute dermal toxicity study indicated that topical administration of maximum concentration of the hydromethanolic crude extract of Bersama abyssinica leaves ointment formulation $(10 \%(\mathrm{w} / \mathrm{w}))$ with a limit dose of $2000 \mathrm{mg} / \mathrm{kg}$ on animals did not show any sign of dermal toxicity as depicted in Figure 5(a) and simple ointment observed in Figure 5(b). With 6-hour special attention and 14-day cage side observation periods, animals showed no sign of edema, erythema, and death (see Figure 5).

\section{Wound Healing Activity of Crude Extracts}

\subsection{Excision Wound Model}

5.1.1. Wound Contraction. Hydromethanolic crude extract ointment formulations of B. abyssinica leaf increased wound contraction in excision wound model compared with mice treated with simple ointment base. Hydromethanolic crude extract of Bersama abyssinica leaves $10 \% \mathrm{w} / \mathrm{w}$ and nitrofurazone $0.2 \%$ ointment enhanced wound contraction significantly $(p<0.01)$ at $4^{\text {th }}$ postwounding day and more significant $(p<0.001)$ from $6^{\text {th }}$ postwounding day onwards as compared with negative control. Likewise, $10 \% \mathrm{w} / \mathrm{w}$ hydromethanolic crude extract of Bersama abyssinica leaves showed significant $(p<0.001, p<0.01)$ wound contraction from $8^{\text {th }}$ to $12^{\text {th }}$ and $14^{\text {th }}$ postwounding days, respectively, compared with mice treated with $5 \%$ w/w crude extract ointment. On the other hand, the mice treated with $5 \%(\mathrm{w} / \mathrm{w})$ extract ointment showed significant wound contraction from $4^{\text {th }}$ to $6^{\text {th }}(p<0.05), 8^{\text {th }}(p<0.01)$, and $10^{\text {th }}$ postwounding day onwards $(p<0.001)$ as compared with mice treated with simple ointment. Slightly higher rate of wound contraction was observed with $10 \%$ w/w crude extract ointment than reference nitrofurazone, but not statically significant (see Table 3).

Higher and comparable percentage of wound contraction on excision wound healing model was observed in groups treated with 5\%,10\% w/w hydromethanolic crude extract of Bersama abyssinica leaves and nitrofurazone $0.2 \%$ $\mathrm{w} / \mathrm{v}$ at $12^{\text {th }}(90.58 \%, 93.73 \%$, and $94.18 \%), 14^{\text {th }}(99.29 \%$, $99.35 \%$, and $97.05 \%)$, and $16^{\text {th }}(99.55 \%, 100 \%$, and $100 \%)$ postwounding days, respectively, and was highly significant $(p<0.001)$ compared with negative control. Complete wound closure was observed in hydromethanolic crude extract $10 \%$ of Bersama abyssinica leaves and nitrofurazone $0.2 \% \mathrm{w} / \mathrm{v}$ at $16^{\text {th }}$ postwounding days, respectively (see Table 4).

5.1.2. Epithelization Period. Topical application of both crude extract ointment and reference drug showed significant reduction in epithelialization period $(p<0.001)$ as compared with mice treated with simple ointment. Time for complete epithelization was reduced by $28.2 \%$ for $10 \%$ (w/ w), $18.8 \%$ for $5 \%(\mathrm{w} / \mathrm{w})$, and $27.4 \%$ for $0.2 \%$ nitrofurazone ointments, respectively. This is evidenced by shorter period for fall of scab (see Table 5).

5.1.3. Histopathological Analysis. Granulation tissue taken from $10 \% \mathrm{w} / \mathrm{w}$ hydromethanolic crude extract treated group showed no inflammatory cells, more collagen fiber, more fibroblasts proliferation, and less blood capillaries (angiogenesis). 5\% w/w hydromethanolic crude extract treated group showed few inflammatory cells, moderate collagen fiber, fibroblasts proliferation, and less blood capillaries (angiogenesis). The reference drug treated group also showed no inflammatory cells, less collagen fiber, less fibroblasts proliferation, and less blood capillaries (angiogenesis) as compared with mice treated with simple ointment. Simple ointment treated group showed less collagen fibers, less fibroblasts proliferation, and no blood capillaries, and more inflammatory cells, thus showing delayed wound healing processes (see Table 6). And photographic comparison of the wound on day 0 (wound creation) and day 16 after treatment of simple ointment, hydromethanolic crude extract, and nitrofurazone ointment is shown in Figure 6 and Photograph of hematoxylin and eosin staining of tissues from partial thickness burn wound model in mice is shown in Figure 7.

\subsection{Linear Incision Wound Healing Study}

5.2.1. Tensile Strength. Both 5\% w/w and 10\% w/w hydromethanolic crude extract and nitrofurazone ointment treated group showed significant $(p<0.001)$ increase in tensile strength as compared with simple ointment base and untreated groups. Percent tensile strength of $10 \%, 5 \%(\mathrm{w} / \mathrm{w})$ hydromethanolic crude extract ointments and nitrofurazone $0.2 \%$ ointment treated group was $61.17,47.5$, and 62.62, respectively (see Table 7 ). 
TABLE 2: Yield of $80 \%$ hydromethanolic leaf crude extract and solvent fractions of B. abyssinica leaf.

\begin{tabular}{lccc}
\hline Name of extract & Amount $(\mathrm{g})$ & Yield in grams & Percent yield \\
\hline Crude extract & 1000 & 173 & 17.3 \\
Aqueous fraction & & 45 & 64.3 \\
Chloroform fraction & \multirow{2}{*}{ grams was dissolved in water } & 7.5 & 10.7 \\
Hexane fraction & & 2.5 & 3.6 \\
\hline
\end{tabular}

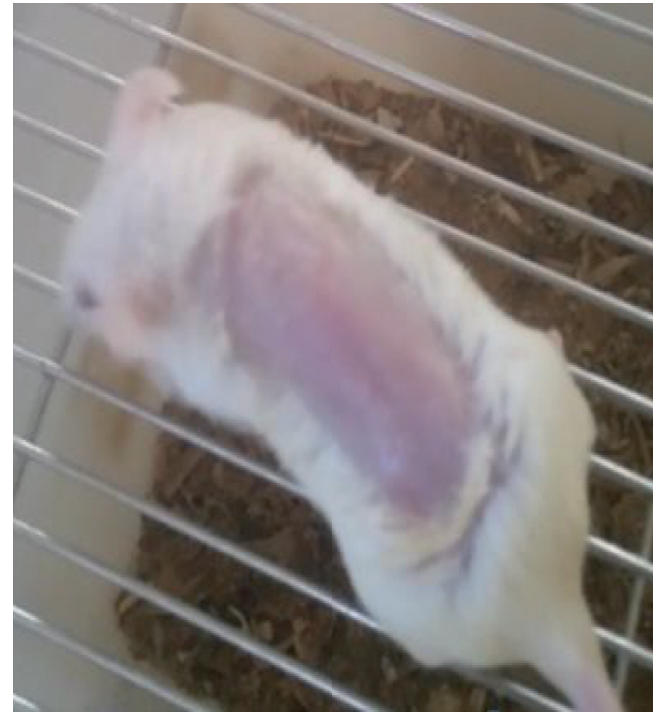

(a)

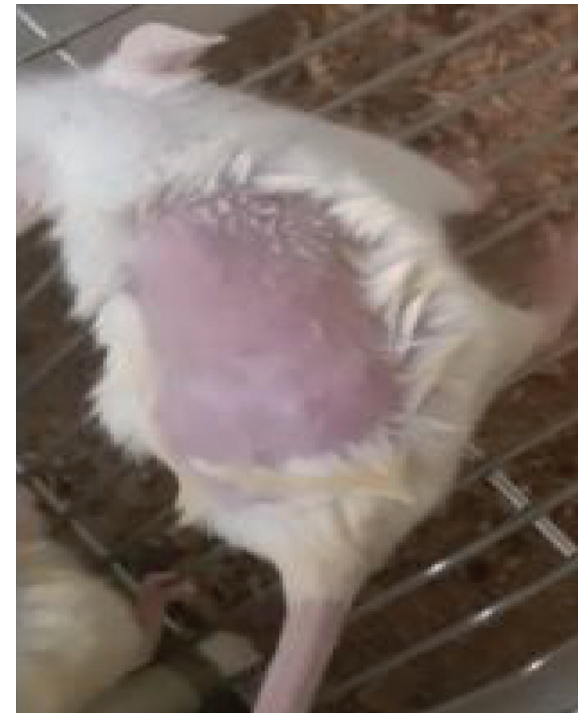

(b)

FIgURE 5: Photographs of acute dermal toxicity test results: (a) hydromethanolic crude extract 10\% w/w and (b) simple ointment.

TABLE 3: Effect of topical application of ointment prepared from $80 \%$ hydromethanolic leaf crude extract of B. abyssinica on wound area $\left(\mathrm{mm}^{2}\right)$ in excision wound model.

\begin{tabular}{|c|c|c|c|c|c|c|c|}
\hline Oint & Day 4 & Day 6 & Day 8 & Day 10 & Day 12 & Day 14 & Day 16 \\
\hline $\mathrm{SOB}$ & & & & & & & \\
\hline $\mathrm{HC}$ & & & & & & & \\
\hline $\mathrm{HC}$ & 2 & $146.00=$ & $89.50 \pm$ & $39.17 \pm 0.95$ & $14.83 \pm 0$ & $1.67 \pm 0.5$ & 0.00 \\
\hline NO $0.2 \% \mathrm{w} / \mathrm{v}$ & $210.83 \pm 3.64^{\mathrm{a} 2}$ & $144.83 \pm 3.45^{\mathrm{a} 3}$ & $92.67 \pm 2.04^{\mathrm{a} 3 \mathrm{~b} 3}$ & $40.67 \pm 1.61^{\mathrm{a} 3 \mathrm{~b} 3}$ & $16.00 \pm 0.73^{\mathrm{a} 3 \mathrm{~b} 3}$ & $1.83 \pm 0.65^{\mathrm{a} 3 \mathrm{~b} 2}$ & $0.00 \pm 0.00^{\mathrm{a} 3}$ \\
\hline
\end{tabular}

Data are expressed as mean \pm SEM; $n=6$, a, compared with simple ointment; b, compared with crude methanolic extract $5 \%$ (w/w); c, compared with crude methanolic extract $10 \%(\mathrm{w} / \mathrm{w})$ ointment; $\mathrm{d}$, compared with nitrofurazone $0.2 \%(\mathrm{w} / \mathrm{v})$ ointment. $1, p<0.05,2, p<0.01$, and 3 , $p<0.001$. SOB, simple ointment base; HCEO, hydromethanolic crude extract of B. abyssinica leaves; NO, nitrofurazone ointment.

TABLE 4: Effect of topical application of ointment prepared from $80 \%$ hydromethanolic leaves crude extract of B. abyssinica on percent wound contraction in excision wound model.

\begin{tabular}{|c|c|c|c|c|c|c|c|}
\hline Oint & Day 4 & Day 6 & Day 8 & Day 10 & Day 12 & Day 14 & Day 16 \\
\hline SOB & & $27+1$ & & 57. & & $45+0$ & \\
\hline & & $39.00 \pm$ & $55.56 \pm 1.04^{\mathrm{a} 3 \mathrm{c}}$ & $77.99 \pm 0$ & $90.58 \pm$ & $97.05 \pm$ & $0.21^{\mathrm{a} 3}$ \\
\hline $\mathrm{HCE}$ & 7.69 & $42.60 \pm 0.45$ & $64.81 \pm 0.41^{\mathrm{a} 3 \mathrm{~b} 3}$ & $84.6 \pm 0.2$ & $94.18 \pm 0.3$ & $99.35=$ & $0.00^{\mathrm{a} 3}$ \\
\hline NO $0.2 \% \mathrm{w} / \mathrm{v}$ & $17.46 \pm 0.34^{\mathrm{a} 3}$ & $43.31 \pm 0.79^{\mathrm{a} 3 \mathrm{~b} 3}$ & $63.7 \pm 0.75^{\mathrm{a} 3 \mathrm{~b} 3}$ & $84.09 \pm 0.53^{\mathrm{a} 3}$ & $93.73 \pm 0.28^{\mathrm{a} 3 \mathrm{~b} 3}$ & $99.29 \pm 0.26^{\mathrm{a} 3 \mathrm{~b} 2}$ & $100 \pm 0.00^{\mathrm{a} 3}$ \\
\hline
\end{tabular}

Data are expressed as mean \pm SEM; $n=6$; a, compared with simple ointment; b, compared with crude methanolic extract $5 \%($ w/w); c, compared with crude methanolic extract $10 \%(\mathrm{w} / \mathrm{w})$ ointment; $\mathrm{d}$, compared with nitrofurazone $0.2 \%(\mathrm{w} / \mathrm{v})$ ointment. $1, p<0.05 ; 2, p<0.01 ; 3, p<0.001$. SOB, simple ointment base; HCEO, hydromethanolic crude extract of $B$. abyssinica leaves; NO, nitrofurazone ointment. 
TABLE 5: Effect of topical application of ointment prepared from $80 \%$ hydromethanolic leaf crude extract of B. abyssinica on epithelization period in excision wound model.

\begin{tabular}{lcc}
\hline Treatment groups & Epithelization period (days) & Percentage reduction epithelization periods \\
\hline Simple ointment base & $19.5 \pm 1.64$ & - \\
Hydromethanolic crude extract ointment $5 \% \mathrm{w} / \mathrm{w}$ & $15.83 \pm 0.40^{\mathrm{a} 3}$ & 18.8 \\
Hydromethanolic crude extract ointment $10 \% \mathrm{w} / \mathrm{w}$ & $14 \pm 0.37^{\mathrm{a} 3}$ & 28.2 \\
Nitrofurazone ointment $0.2 \%(\mathrm{w} / \mathrm{v})$ & $14.17 \pm 0.40^{\mathrm{a} 3}$ & 27.4 \\
\hline
\end{tabular}

Data are expressed as mean $\pm \mathrm{SEM} ; n=6$; $\mathrm{SOB}=$ simple ointment base, $\mathrm{HCEO}=$ hydromethanolic crude extract ointment, $\mathrm{NO}=$ nitrofurazone ointment; a, compared with simple ointment; b, compared with crude methanolic extract $5 \%(w / w) ; c$, compared with crude methanolic extract $10 \%$ (w/w) ointment; d, compared with nitrofurazone $0.2 \%(\mathrm{w} / \mathrm{v})$ ointment. $1, p<0.05 ; 2, p<0.01 ; 3, p<0.001$.

TABLE 6: Histological qualitative determination of wound healing processes and healing phases of B. abyssinica crude extract ointment in excision wound model in mice.

\begin{tabular}{lcccccc}
\hline Group & $\begin{array}{c}\text { Inflammatory } \\
\text { cells }\end{array}$ & $\begin{array}{c}\text { Fibroblast } \\
\text { proliferation }\end{array}$ & $\begin{array}{c}\text { Collagen } \\
\text { depositions }\end{array}$ & $\begin{array}{c}\text { Mononuclear } \\
\text { cells }\end{array}$ & $\begin{array}{c}\text { Polymorphonuclear } \\
\text { cells }\end{array}$ & Neovascularization \\
\hline SOB & +++ & + & + & - & ++ & - \\
HCEO 5\% & + & ++ & ++ & - & - & + \\
HCEO & - & ++ & + & - & + \\
10\% & - & + & + & - & + \\
NO 0.2\% & - & + & - & + \\
\hline
\end{tabular}

Low concentration $(+)$, moderate concentration $(++)$, and high concentration $(+++)$ for epidermal and/or dermal remodeling. SOB, Simple ointment base; HCEO, hydromethanolic crude extract of B. abyssinica leaves; NO, nitrofurazone ointment.

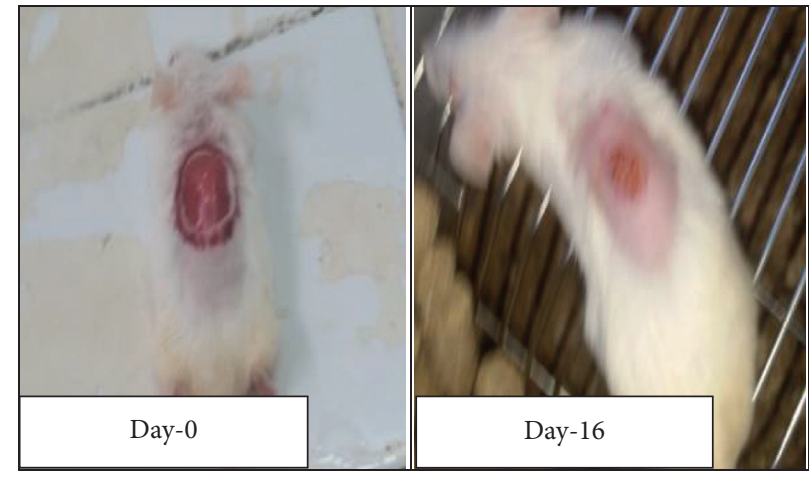

(a)

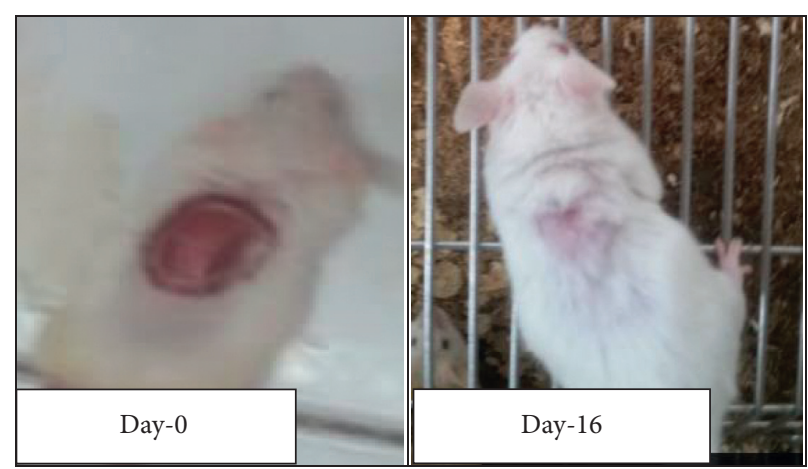

(c)
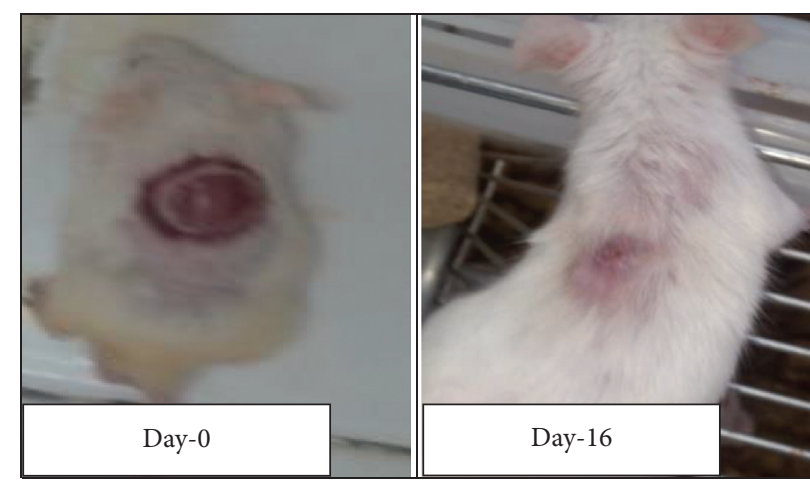

(b)
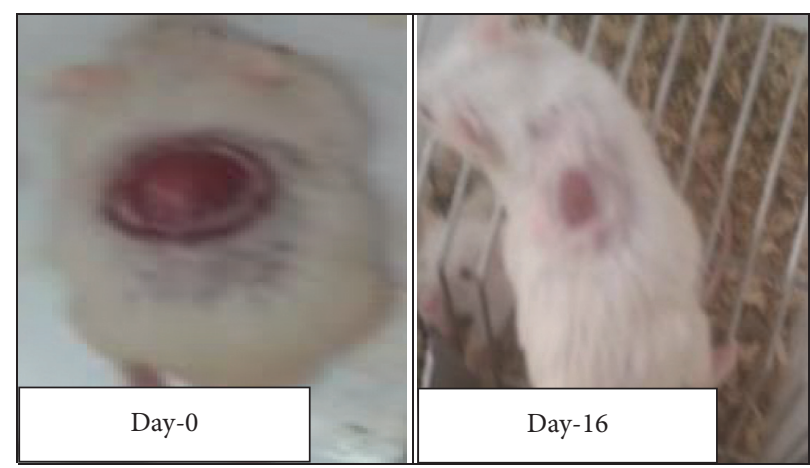

(d)

FIgURE 6: Photographic comparison of wound contraction on mice treated with simple ointment, nitrofurazone ointment, and hydromethanolic crude extract on excision wound model. (a) Mice treated with simple ointment base. (b) Mice treated with hydromethanolic extract $5 \% \mathrm{w} / \mathrm{w}$ ointment. (c) Mice treated with hydromethanolic extract $10 \% \mathrm{w} / \mathrm{w}$ ointment. (d) Mice treated with nitrofurazone $0.2 \% \mathrm{w} / \mathrm{v}$ ointment. 

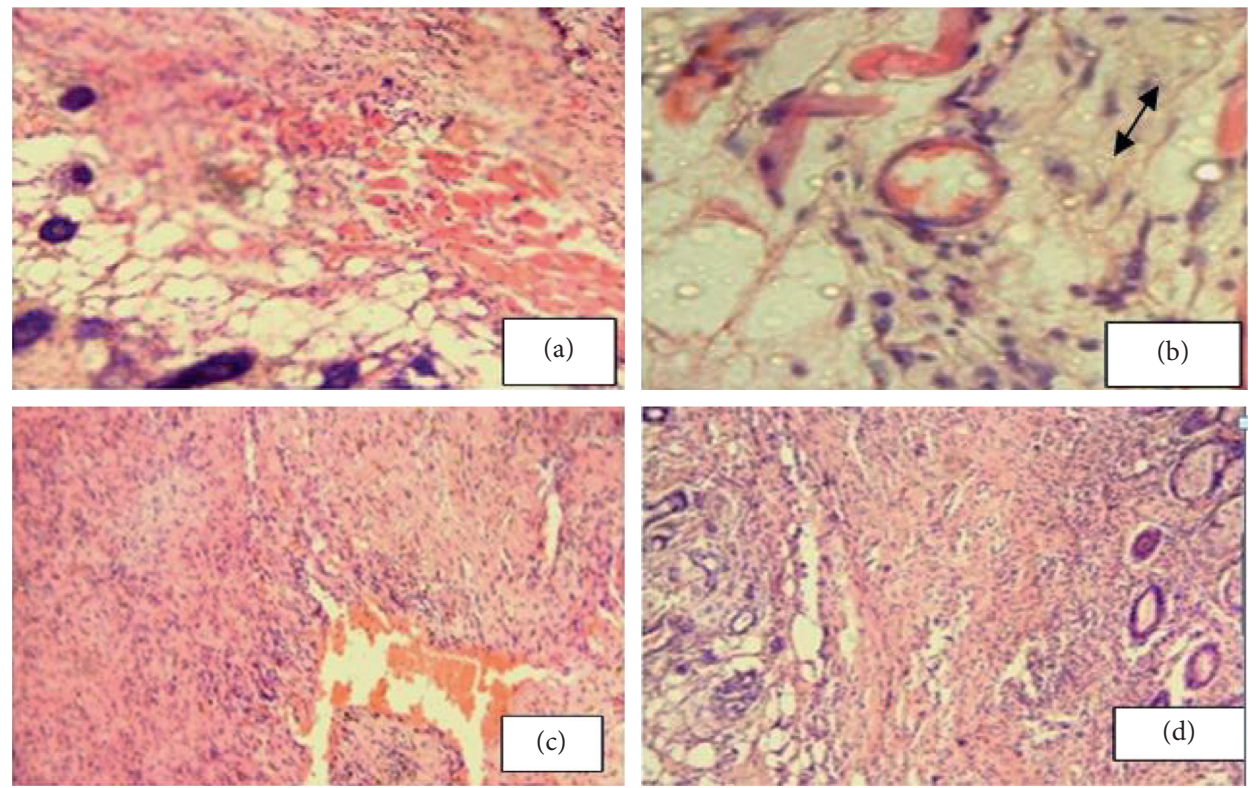

Figure 7: Photograph of hematoxylin and eosin staining of tissues from partial thickness burn wound model in mice. (a) Mice treated with simple ointment. (b) Mice treated with 5\% crude extract ointment. (c) Mice treated with $10 \%$ crude extract ointment. (d) Mice treated with nitrofurazone.

TABLE 7: Effect of topical application of hydromethanolic crude extract of B. abyssinica leaves on tensile strength in incision wound model in mice.

\begin{tabular}{lcc}
\hline Treatment groups & Tensile strength in grams & Percent tensile strength \\
\hline Untreated & $210.5 \pm 3.03$ & - \\
Simple ointment base & $240.33 \pm 6.42$ & 14.17 \\
Hydromethanolic crude extract ointment $5 \% \mathrm{w} / \mathrm{w}$ & $354.5 \pm 9.2^{\mathrm{a} 3 \mathrm{~b} 3}$ & 47.5 \\
Hydromethanolic crude extract ointment $10 \% \mathrm{w} / \mathrm{w}$ & $387.33 \pm 16.61^{\mathrm{ab} 3}$ & 61.17 \\
Nitrofurazone ointment $0.2 \% \mathrm{w} / \mathrm{v}$ & $390.83 \pm 10.39^{\mathrm{a} 3 \mathrm{~b} 3}$ & 62.62 \\
\hline
\end{tabular}

Data are expressed as mean \pm SEM; $n=6$; a, compared with untreated group; $\mathbf{b}$, compared with simple ointment; $3, p<0.001$.

\subsection{Burn Wound Healing Activity}

5.3.1. Wound Contraction. Hydromethanolic crude extract at $5 \% \mathrm{w} / \mathrm{w}, 10 \% \mathrm{w} / \mathrm{w}$, and nitrofurazone $0.2 \%$ ointment showed enhanced wound contraction in partial thickness burn wound model as compared with mice treated with simple ointment. Hydromethanolic crude extract at $10 \% \mathrm{w} /$ $\mathrm{w}$ and nitrofurazone $0.2 \%$ ointment started to show significant $(p<0.01)$ wound contraction at $4^{\text {th }}$ postwounding day and enhance it more significantly $(p<0.001)$ from $6^{\text {th }}$ postwounding day onwards as compared with simple ointment base. Likewise, hydromethanolic crude extract $10 \% \mathrm{w} / \mathrm{w}$ showed significant $(p<0.05$ to 0.01$)$ wound contraction from $6^{\text {th }}$ to $18^{\text {th }}$ postwounding days as compared with hydromethanolic crude extract $5 \% \mathrm{w} / \mathrm{w}$. On the other hand, hydromethanolic crude extract $5 \% \mathrm{w} / \mathrm{w}$ recorded significant wound contraction from $6^{\text {th }}(p<0.05)$ and $8^{\text {th }}$ postwounding day onwards $(p<0.001)$ as compared with simple ointment treated mice. Reference drug showed slightly higher rate of wound contraction as compared with hydromethanolic crude extract $10 \% \mathrm{w} / \mathrm{w}$ but lacks statistical significance. Complete wound closure was observed in hydromethanolic crude extract and nitrofurazone $0.2 \%$ ointment at $20^{\text {th }}, 20^{\text {th }}$, and $20^{\text {th }}$ postwounding days, respectively, but simple ointment treated animal was beyond $22^{\text {nd }}$ postwounding day (see Table 8 ).

Higher and comparable percentage of wound contraction was recorded in groups treated with $5 \%, 10 \% \mathrm{w} / \mathrm{w}$ hydromethanolic crude extract, and nitrofurazone at $12^{\text {th }}$ $(63.6 \%, 68.17 \%$, and $69.27 \%), 14^{\text {th }}(82.34 \%, 81.47 \%$, and $77.08 \%)$, and $16^{\text {th }}(91.97 \%, 90.42 \%$, and $87.71 \%)$ postwounding days respectively. Complete wound closure was observed in nitrofurazone $0.2 \%, 10 \%(\mathrm{w} / \mathrm{w}), 5 \%(\mathrm{w} / \mathrm{w})$ hydromethanolic crude extract and simple ointment treated groups were at $20^{\text {th }}, 20^{\text {th, }} 22^{\text {nd }}$, and $24^{\text {th }}$ postwounding days, respectively (see Table 9).

5.4. Epithelization Period. Hydromethanolic crude extract $10 \% \mathrm{w} / \mathrm{w}$ crude extract ointment treated animals showed significant $(p<0.01, p<0.001)$ reduction of epithelization period as compared with hydromethanolic crude extract $5 \%$ and simple ointment treated mice, respectively. Likewise, hydromethanolic crude extract 5\% w/w decreases epithelization period significantly $(p<0.001)$ to mice treated with simple ointment. Hydromethanolic crude extract 10\%, 5\%, 
TABLE 8: Effect of topical application of ointment prepared from $80 \%$ hydromethanolic crude extract of B. abyssinica leaves on wound area contraction $\left(\mathrm{mm}^{2}\right)$ in burn wound model in mice.

\begin{tabular}{|c|c|c|c|c|}
\hline Days & Simple ointment & Methanolic crude extract $5 \%(\mathrm{w} / \mathrm{w})$ & Methanolic crude extract $10 \%(\mathrm{w} / \mathrm{w})$ & Nitrofurazone $0.2 \%(\mathrm{w} / \mathrm{v})$ \\
\hline 2 & $282.33 \pm 4.89$ & $272.17 \pm 5.24$ & $272.00 \pm 5.05$ & $271.83 \pm 4.73$ \\
\hline 4 & $254.33 \pm 5.10$ & $237.17 \pm 4.21$ & $233.17 \pm 4.48^{\mathrm{al}}$ & $232.00 \pm 4.12^{\mathrm{a} 1}$ \\
\hline 6 & $227.00 \pm 3.69$ & $208.00 \pm 3.25^{\mathrm{a} 1 \mathrm{cld} 2}$ & $190.67 \pm 4.56^{\mathrm{a} 3 \mathrm{~b} 2}$ & $186.83 \pm 4.44^{\mathrm{a} 3 \mathrm{~b} 2}$ \\
\hline 8 & $195.50 \pm 4.46$ & $167.67 \pm 3.14^{\mathrm{a} 1 \mathrm{c} 1 \mathrm{~d} 2}$ & $150.67 \pm 3.25^{\mathrm{a} 3 \mathrm{~b} 1}$ & $144.00 \pm 4.07^{\mathrm{a} 3 \mathrm{~b} 2}$ \\
\hline 10 & $165.83 \pm 3.83$ & $134.83 \pm 2.77^{\mathrm{a} 3 \mathrm{c} 2 \mathrm{~d} 3}$ & $117.83 \pm 1.54^{\mathrm{a} 3 \mathrm{~b} 2}$ & $113.50 \pm 2.77^{\mathrm{a} 3 \mathrm{~b} 3}$ \\
\hline 12 & $135.00 \pm 3.77$ & $99.00 \pm 3.07^{\mathrm{a} 3 \mathrm{cld} 2}$ & $86.33 \pm 3.20^{\mathrm{a} 3 \mathrm{~b} 2}$ & $83.50 \pm 1.93^{\mathrm{a} 3 \mathrm{~b} 2}$ \\
\hline 14 & $105.17 \pm 3.79$ & $62.50 \pm 3.11^{\mathrm{a} 3 \mathrm{c} 2 \mathrm{~d} 2}$ & $50.17 \pm 2.40^{\mathrm{a} 3 \mathrm{~b} 2}$ & $48.00 \pm 1.83^{\mathrm{a} 3 \mathrm{~b} 2}$ \\
\hline 16 & $76.67 \pm 2.49$ & $33.67 \pm 2.99^{\mathrm{a} 3 \mathrm{~d} 2}$ & $26.00 \pm 1.39^{\mathrm{a} 3}$ & $21.83 \pm 1.56^{\mathrm{a} 3 \mathrm{~b} 2}$ \\
\hline 18 & $49.50 \pm 3.63$ & $9.83 \pm 1.47^{\mathrm{a} 3 \mathrm{~d} 2}$ & $3.33 \pm 0.76^{\mathrm{a} 3}$ & $1.33 \pm 0.71^{\mathrm{a} 3 \mathrm{~b} 2}$ \\
\hline 20 & $17.67 \pm 3.03$ & $0.50 \pm 0.34^{\mathrm{a} 3}$ & $0.00 \pm 0.00^{\mathrm{a} 3}$ & $0.00 \pm 0.00^{\mathrm{a} 3}$ \\
\hline 22 & $3.50 \pm 1.23$ & $0.00 \pm 0.00^{\mathrm{a} 2}$ & $0.00 \pm 0.00^{\mathrm{a} 2}$ & $0.00 \pm 0.00^{\mathrm{a} 2}$ \\
\hline 24 & $0.00 \pm 0.00$ & $0.50 \pm 0.34$ & $0.00 \pm 0.00$ & $0.00 \pm 0.00$ \\
\hline
\end{tabular}

Data are expressed as mean \pm SEM; $n=6$, a, compared with simple ointment; b, compared with crude methanolic extract $5 \%$ (w/w); c, compared with crude methanolic extract $10 \%(\mathrm{w} / \mathrm{w})$ ointment; d, compared with nitrofurazone $0.2 \%(\mathrm{w} / \mathrm{v})$ ointment. $1, p<0.05 ; 2, p<0.01 ; 3, p<0.001$.

TABLE 9: Effect of topical application of ointment prepared from $80 \%$ hydromethanolic leaf crude extract of B. abyssinica on percent wound contraction in burn wound model.

\begin{tabular}{lcccc}
\hline $\begin{array}{l}\text { Data collection } \\
\text { days }\end{array}$ & $\begin{array}{c}\text { Simple } \\
\text { ointment }\end{array}$ & $\begin{array}{c}\text { Hydromethanolic crude extract } \\
5 \%(\mathrm{w} / \mathrm{w})\end{array}$ & $\begin{array}{c}\text { Hydromethanolic crude extract } \\
10 \%(\mathrm{w} / \mathrm{w})\end{array}$ & $\begin{array}{c}\text { Nitrofurazone ointment } \\
0.2 \%(\mathrm{w} / \mathrm{v})\end{array}$ \\
\hline 2 & 0.00 & 0.00 & 0.00 & 0.00 \\
4 & $9.93 \pm 0.54$ & $12.84 \pm 0.58^{\mathrm{a} 1}$ & $14.25 \pm 1.02^{\mathrm{a} 1}$ & $14.65 \pm 0.64^{\mathrm{a} 1}$ \\
6 & $19.59 \pm 0.25$ & $23.52 \pm 1.00^{\mathrm{a} 1 \mathrm{c} 2 \mathrm{~d} 3}$ & $29.87 \pm 1.42^{\mathrm{a} \mathrm{b} 2}$ & $31.29 \pm 0.82^{\mathrm{abb} 3}$ \\
8 & $30.75 \pm 1.04$ & $38.35 \pm 1.08^{\mathrm{a} 2 \mathrm{c} 2 \mathrm{~d} 3}$ & $44.52 \pm 1.52^{\mathrm{abb} 2}$ & $47.04 \pm 1.00^{\mathrm{a} 3 \mathrm{~b} 3}$ \\
10 & $41.26 \pm 0.93$ & $50.41 \pm 1.10^{\mathrm{a} 3 \mathrm{c} 2 \mathrm{~d} 3}$ & $56.57 \pm 1.25^{\mathrm{a} b 2}$ & $58.26 \pm 0.56^{\mathrm{a} b 3}$ \\
12 & $52.15 \pm 1.27$ & $63.6 \pm 1.05^{\mathrm{a} 3 \mathrm{~b} 3 \mathrm{~d} 2}$ & $68.17 \pm 1.47^{\mathrm{a} 3 \mathrm{~b} 1}$ & $69.27 \pm 0.56^{\mathrm{a} \mathrm{b} 2}$ \\
14 & $62.72 \pm 1.33$ & $77.08 \pm 0.85^{\mathrm{a} 3 \mathrm{cld} 2}$ & $81.47 \pm 1.14^{\mathrm{a} b 1 \mathrm{~b} 1}$ & $82.34 \pm 0.59^{\mathrm{a} 3 \mathrm{~b} 2}$ \\
16 & $72.82 \pm 0.88$ & $87.71 \pm 0.89^{\mathrm{a} \mathrm{d} 2}$ & $90.42 \pm 0.57^{\mathrm{a} 3}$ & $91.97 \pm 0.53^{\mathrm{a} \mathrm{b} 2}$ \\
18 & $82.45 \pm 1.28$ & $96.43 \pm 0.48^{\mathrm{a} \mathrm{d} 1}$ & $98.76 \pm 0.29^{\mathrm{a} 3}$ & $99.52 \pm 0.26^{\mathrm{a} 3 \mathrm{~b} 1}$ \\
20 & $93.7 \pm 1.10$ & $99.82 \pm 0.12^{\mathrm{a} 3}$ & $100 \pm 0.00^{\mathrm{a} 3}$ & $100 \pm 0.00^{\mathrm{a} 3}$ \\
22 & $98.75 \pm 0.43$ & $100 \pm 0.00^{\mathrm{a} 2}$ & $100 \pm 0.00^{\mathrm{a} 2}$ & $100 \pm 0.00^{\mathrm{a} 3}$ \\
24 & $100 \pm 0.00$ & $99.82 \pm 0.12$ & $100 \pm 0.00$ & $100 \pm 0.00$ \\
\hline
\end{tabular}

Data are expressed as mean \pm SEM; $n=6$; a, compared with simple ointment; b, compared with crude methanolic extract $5 \%$ (w/w); c, compared with crude methanolic extract $10 \%(\mathrm{w} / \mathrm{w})$ ointment; $d$, compared with nitrofurazone $0.2 \%(\mathrm{w} / \mathrm{v})$ ointment. $1, p<0.05 ; 2, p<0.01 ; 3, p<0.001$.

and nitrofurazone $0.2 \%$ ointment reduce epithelization period with $21.7 \%, 13 \%$, and $22.5 \%$, respectively. However, epithelization periods of hydromethanolic crude extract $10 \%$ w/w extract ointment and nitrofurazone $0.2 \%$ ointment were not statistically significant (see Figure 8).

5.5. Histopathological Analysis. Granulation tissue taken from $10 \% \mathrm{w} / \mathrm{w}$ hydromethanolic crude extract treated group showed few inflammatory cells, modest collagen fiber, less fibroblasts proliferation, and modest blood capillaries (angiogenesis). $5 \% \mathrm{w} / \mathrm{w}$ hydromethanolic crude extract treated group showed few inflammatory cells, few collagen fiber, and fibroblasts proliferation and less blood capillaries (angiogenesis). The reference drug treated group also showed less inflammatory cells, modest collagen fiber, modest fibroblasts proliferation, and moderate blood capillaries (angiogenesis) as compared with simple ointment treated group. Simple ointment treated group showed less collagen fibers, less fibroblasts proliferation, and more inflammatory cells, thus showed delayed wound healing processes (see Table 10). And photographic comparison of the wound on day 0 (wound creation) and day-16 after treatment of simple ointment, hydromethanolic crude extract, and nitrofurazone ointment is shown in Figure 9.

\section{Wound Healing Activity of Solvent Fractions}

6.1. Wound Contraction. All of the solvent fractions ointment preparations promoted wound healing as compared with mice treated with simple ointment. From $4^{\text {th }}$ postwounding day onwards, aqueous fraction ointments $(10 \% \mathrm{w} / \mathrm{w}$ and $5 \% \mathrm{w} / \mathrm{w})$ and nitrofurazone $0.2 \%$ ointment recorded significant $(p<0.001)$ wound contraction as compared with simple ointment. Both chloroform fraction ointments showed significant $(p<0.05$ to 0.001$)$ wound contraction from $4^{\text {th }}$ to $16^{\text {th }}$ postwounding days as compared with negative control. Likewise, $10 \% \mathrm{w} / \mathrm{w}$ chloroform fraction ointment recorded significant $(p<0.05$ to 0.001$)$ wound contraction as compared with both hexane $(5 \% \mathrm{w} / \mathrm{w}$ and $10 \% \mathrm{w} / \mathrm{w})$ fraction ointment treated groups. From $12^{\text {th }}$ to $16^{\text {th }}$ postwounding days, $5 \% \mathrm{w} / \mathrm{w}$ and $10 \% \mathrm{w} / \mathrm{w}$ hexane fraction ointment enhanced wound contraction more 


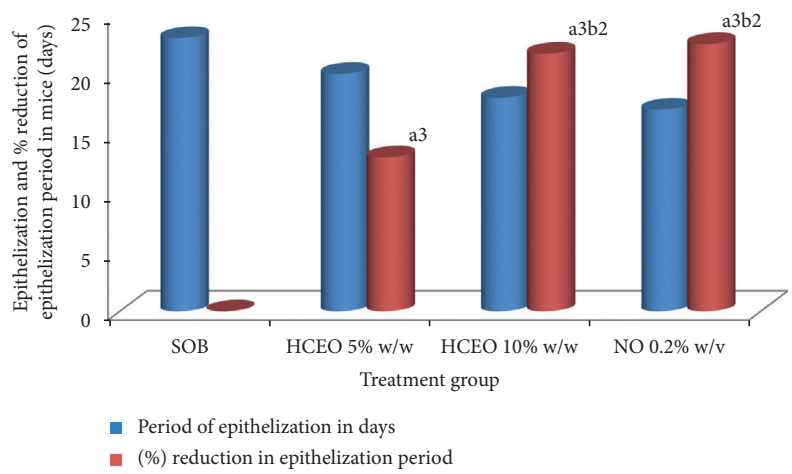

FIGURE 8: Effect of hydromethanolic crude extract of $B$. abyssinica on period of epithelialization and percent reduction in epithelization period on partial thickness wound model in mice. $\mathrm{SOB}=$ simple ointment base, $\mathrm{HCEO}=$ hydromethanolic crude extract ointment, $\mathrm{NO}=$ nitrofurazone ointment. (a) Compared with simple ointment; (b) compared with 5\% w/w: $2 p<0.01,3 p<0.001$.

TABLE 10: Histological qualitative determination of wound healing processes and healing phases of B. abyssinica leaf hydromethanolic crude extract ointment in partial thickness wound model in mice.

\begin{tabular}{lcccccc}
\hline Group & $\begin{array}{c}\text { Inflammatory } \\
\text { cells }\end{array}$ & $\begin{array}{c}\text { Fibroblast } \\
\text { proliferation }\end{array}$ & $\begin{array}{c}\text { Collagen } \\
\text { depositions }\end{array}$ & $\begin{array}{c}\text { Mononuclear } \\
\text { cells }\end{array}$ & $\begin{array}{c}\text { Polymorphonuclear } \\
\text { cells }\end{array}$ & Neovascularization \\
\hline SOBS & +++ & + & + & - & + & +++ \\
HCEO 5\% & + & + & + & + & + & + \\
HCEO10\% & + & + & ++ & + & + & + \\
NO 0.2\% & + & ++ & + & + & + & ++ \\
\hline
\end{tabular}

Low concentration $(+)$, moderate concentration $(++)$, and high concentration $(+++)$ for epidermal and/or dermal remodeling. SOB, Simple ointment base; HCEO, hydromethanolic crude extract of B. abyssinica leaves; NO, nitrofurazone ointment.

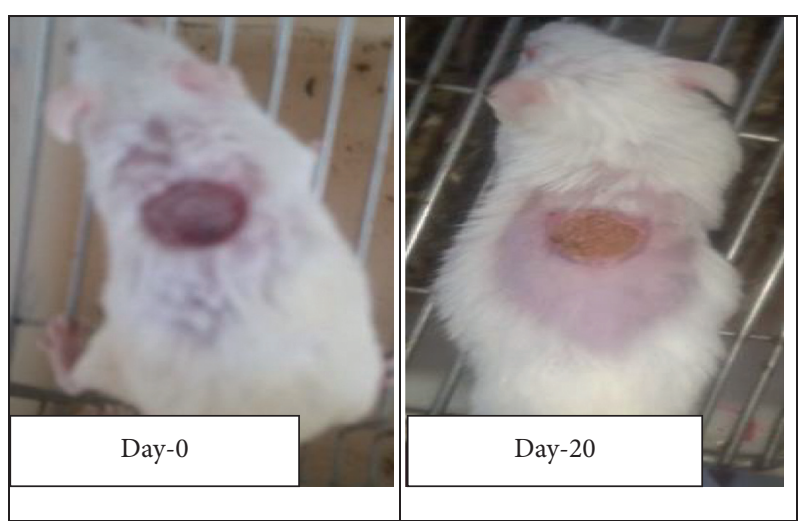

(a)

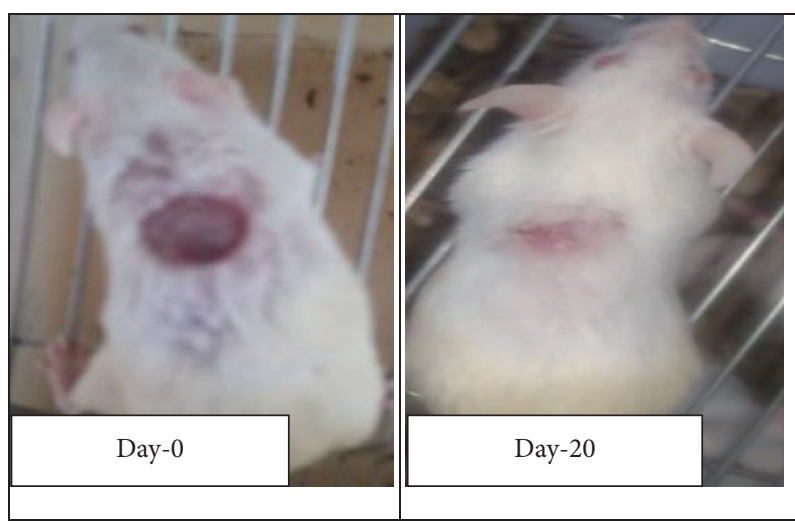

(c)

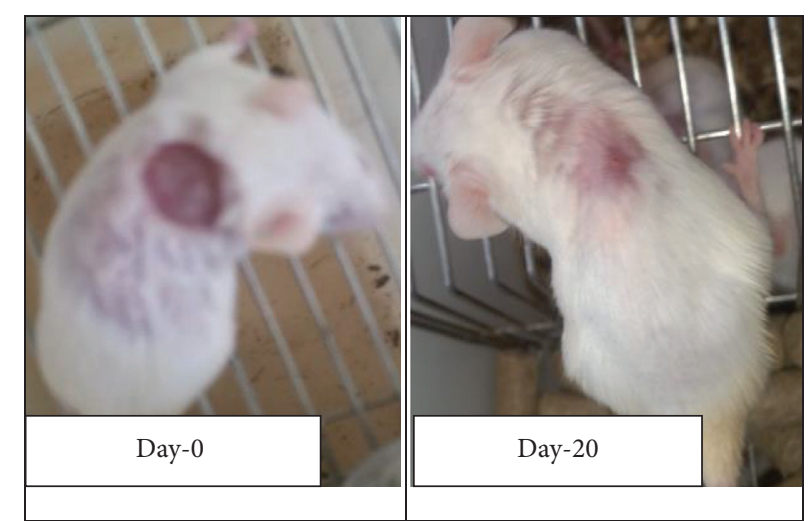

(b)

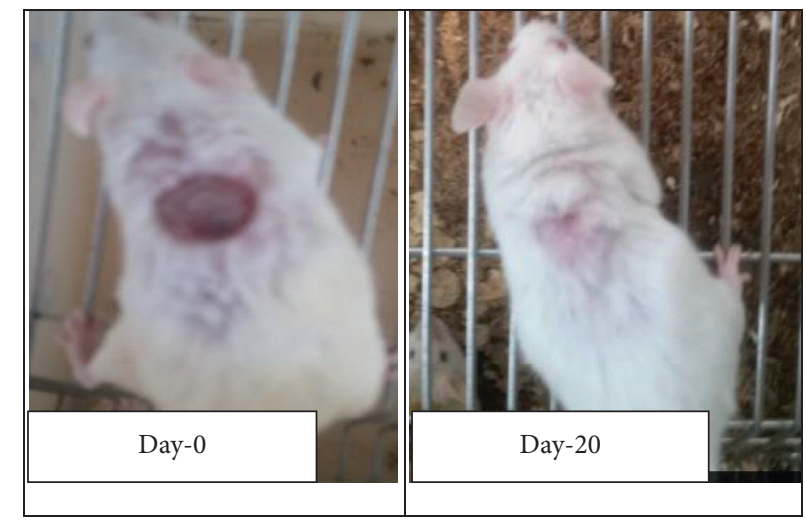

(d)

Figure 9: Photographic comparison of wound contraction on mice treated with simple ointment, nitrofurazone ointment, and hydromethanolic crude extract on burn wound model. (a) Mice treated with simple ointment base. (b) Mice treated with hydromethanolic extract $5 \% \mathrm{w} / \mathrm{w}$ ointment. (c) Mice treated with hydromethanolic extract $10 \% \mathrm{w} / \mathrm{w}$ ointment. (d) Mice treated with nitrofurazone $0.2 \% \mathrm{w} / \mathrm{v}$ ointment. 
significantly $(p<0.001)$ as compared with simple ointment. There was a slightly higher effect with $(10 \% \mathrm{w} / \mathrm{w})$ ointment preparations than $(5 \% \mathrm{w} / \mathrm{w})$ ointment preparations between each solvent fractions, but lacking statistical significance between high and low strengths. Similarly, there was modest difference between both aqueous fraction and reference drug, but not significant (see Table 11).

Higher percentage of wound contraction was observed from $14^{\text {th }}$ postwounding day on wards on mice treated with aqueous fraction $(10 \% \mathrm{w} / \mathrm{w}, 5 \% \mathrm{w} / \mathrm{w})$ and nitrofurazone $0.2 \%$ ointment, and the remaining fraction ointments were shown at $16^{\text {th }}$ postwounding day. Complete wound closure of aqueous fraction ( 5 and 10\%), chloroform fraction (5 and $10 \%$ ), hexane fraction (5 and $10 \%$ ), and nitrofurazone $0.2 \%$ was $16^{\text {th }}, 17^{\text {th }}, 18^{\text {th }}$, and $16^{\text {th }}$ postwounding days, respectively, but negative control wound closure was beyond $18^{\text {th }}$ postwounding day (see Table 12).

6.2. Epithelization Periods of Fraction. All 5\% w/w and $10 \%$ $\mathrm{w} / \mathrm{w}$ fraction ointments could shorten the period of epithelialization against the animals treated with simple ointment. Animals treated with aqueous (5\% and 10\%) w/w fraction ointments and reference drug could shorten epithelization period more significantly $(p<0.001)$ as compared with simple ointment treated group and other fractions. Both strengths of hexane fraction ointment were significant $(p<0.05)$ as compared with negative control. There was no significant difference between the treatment doses of the three fractions, as well as with the positive control. Percentage reduction in epithelization period was higher for $5 \%$ water fraction $(28.6 \%)$ and minimum for $5 \%$ hexane fraction $(7.1 \%)$. There was a modest difference between epithelization period of $5 \%$ and $10 \%$ preparations of each fraction, but lacking significance when compared with each other (see Table 13). And photographic comparison of the wound on day 0 (wound creation) and day-16 after treatment of simple ointment, hydromethanolic crude extract, and nitrofurazone ointment was shown in Figure 10.

\section{Discussion}

Wound healing may be a fancy process, involving many biochemical process and cellular reactions. In wound management, sensitivity and skin irritations are common side effects, which diminish the speed of skin repair and increase the healing periods [52].

Traditionally, many medicinal plants support the speed of wound healing with minimal pain, discomfort, and scarring to the patient [47]. Majority of these plants are scientifically validated for their wound healing effects. The experimental plant $B$. abyssinica is among these plants traditionally used as a wound healing agent in several communities of Ethiopia. Except this study, no prior scientific evaluation in vivo was conducted for its wound healing activities. Therefore, this study was performed to scientifically assess the potential of this plant as an alternate treatment in wound healing in vivo. In vivo models are the foremost predictive models for studying wound healing, allowing a wise representation of the wound environment including various cell types and environmental cues. We chose mice for this study by considering cost and availability of them in conducting preliminary pharmacological screening [52].

For evaluation of plant wound healing effect in mice model, applying the fabric on to the wounded area cannot bring the desired effect. Hence, first, the leaves of B. abyssinica were extracted with $80 \%$ hydromethanol with maceration technique to separate medicinally active portion from insoluble cellular marc. Methanol was chosen for extraction because it is a solvent and has produced many phytochemicals of this plant from previous studies. Maceration technique is additionally more applicable, convenient, and among fewer costly methods for little and medium plant extractions $[9,53]$.

Topical application of plant extract only at wound site is additionally easily removed. It must be incorporated in simple ointment bases to achieve the specified effect by sustained release of extract at the application site. Ointment bases may form barrier for moisture over the wound area, which is crucial for cellular migration and diffusion of growth factors to wound [45].

No edema and irritation on mice observed with acute dermal toxicity test could indicate the security of the plant to be used as wound management. As explained above, irritation is the main side effect of wound managements.

Evaluation of $B$. abyssinica leaves hydromethanolic crude extract wound healing effect in an exceedingly single wound model was inadequate, and there is no reference standard, which could collectively represent the various components of wound healing phases [54]. Hence, different wound healing models, namely, linear incision, circular excision, and partial thickness burn wound models, were used.

In the present study, various parameters like wound contraction, epithelization, and strength were assessed in the above explained wound models to determine the speed of healing. The results of the study on excision wound model indicated that wound contraction rate observed from $10 \%$ (w/w) hydromethanolic crude extract ointment treated group was resembling the standard drug nitrofurazone, more significant than negative control, and better than $5 \%$ w/w hydromethanolic crude extract for several postwounding days. Likewise, 5\% w/w hydromethanolic crude extract reduces wound area significantly from 8th postwounding day onwards as compared with negative control.

The finding of burn wound study showed that wound contraction rate observed in $10 \%(\mathrm{w} / \mathrm{w})$ hydromethanolic crude extract ointment treated group was slightly different from that of nitrofurazone, more significant than negative control altogether postwounding days, and 5\%w/w hydromethanolic crude extract ointment for several postwounding days.

Wound Contraction is also a movement of wound edges toward each other in a centripetal fashion. This is often important to decrease the wound's dimensions, reduce the amount of extracellular matrix needed to repair the defect, and desire less granulation to exchange tissue loss [55]. The 
TABLE 11: Effect of topical application of ointment prepared from solvent fractions of B. abyssinica leaves on wound area contraction (mm ${ }^{2}$ ) in excision wound model in mice.

\begin{tabular}{|c|c|c|c|c|c|c|c|}
\hline Ointment & Day 4 & Day 6 & Day 8 & Day 10 & Day 12 & Day 14 & Day 16 \\
\hline SOB & $258.33 \pm 2.67$ & $224.33 \pm 2.55$ & $184.17 \pm 4.22$ & $148.00 \pm 2.88$ & $106.17 \pm 2.68$ & $68.67 \pm 2.77$ & $32.50 \pm 1.29$ \\
\hline AQF $5 \% \mathrm{w} / \mathrm{w}$ & $233.17 \pm 1.96^{\mathrm{a} 3}$ & $195.50 \pm 4.24^{\mathrm{a} 3}$ & $148.17 \pm 2.17^{\mathrm{a} 3}$ & $88.50 \pm 1.96^{\mathrm{a} 3}$ & $39.33 \pm 0.67^{\mathrm{a} 3}$ & $2.17 \pm 1.11^{\mathrm{a} 3}$ & $0.00 \pm 0.00^{\mathrm{a} 3}$ \\
\hline AQF $10 \% \mathrm{w} / \mathrm{w}$ & $227.83 \pm 1.92^{\mathrm{a} 3}$ & $195.00 \pm 3.83^{\mathrm{a} 3}$ & $146.17 \pm 1.30^{\mathrm{a} 3}$ & $86.83 \pm 1.70^{\mathrm{a} 3}$ & $38.67 \pm 1.05^{\mathrm{a} 3}$ & $1.67 \pm 0.76^{\mathrm{a} 3}$ & $0.00 \pm 0.00^{\mathrm{a} 3}$ \\
\hline $\mathrm{CHF} 5 \% \mathrm{w} / \mathrm{w}$ & $243.67 \pm 3.40^{\mathrm{a} 1 \mathrm{~d} 2}$ & $215.67 \pm 1.84^{\mathrm{ald} 3}$ & $169.83 \pm 2.01^{\text {ald } 3}$ & $126.17 \pm 1.54^{\mathrm{a} 3 \mathrm{~d} 3}$ & $75.17 \pm 1.54^{\mathrm{a} 3 \mathrm{~d} 3}$ & $27 \pm 2.16^{\mathrm{a} 3 \mathrm{~d} 3}$ & $2.33 \pm 0.84^{\mathrm{a} 3}$ \\
\hline $\mathrm{CHF} 10 \% \mathrm{w} / \mathrm{w}$ & $241.83 \pm 3.79^{\mathrm{a} 2 \mathrm{~d} 1}$ & $212.50 \pm 1.23^{\mathrm{a} 2 \mathrm{~d} 3}$ & $164.33 \pm 3.16^{\mathrm{a} 2 \mathrm{~d} 2}$ & $124.00 \pm 2.75^{\mathrm{a3d} 3}$ & $73 \pm 1.88^{\mathrm{a} 3 \mathrm{~d} 3}$ & $24.83 \pm 1.62^{\mathrm{a} 3 \mathrm{~d} 3}$ & $1.83 \pm 0.91^{\mathrm{a} 3}$ \\
\hline HF 5\% w/w & $246.33 \pm 4.86^{\mathrm{d} 2}$ & $218.33 \pm 5.06^{\mathrm{d} 3}$ & $183.33 \pm 4.02^{\mathrm{d} 3}$ & $135.67 \pm 2.06^{\mathrm{a} 2 \mathrm{~d} 3}$ & $82.33 \pm 1.80^{\mathrm{a} 3 \mathrm{~d} 3}$ & $39.5 \pm 1.29^{\mathrm{a} 3 \mathrm{~d} 3}$ & $5.00 \pm 0.58^{\mathrm{a} 3 \mathrm{~d} 2}$ \\
\hline HF $10 \% \mathrm{w} / \mathrm{w}$ & $248.00 \pm 3.92^{\mathrm{d} 2}$ & $217.83 \pm 2.70^{\mathrm{d} 2}$ & $181.50 \pm 4.05^{\mathrm{d} 3}$ & $133.00 \pm 1.59^{\mathrm{a} 3 \mathrm{~d} 3}$ & $79.5 \pm 1.48^{\mathrm{a} 3 \mathrm{~d} 3}$ & $36.67 \pm 1.05^{\mathrm{a} 3 \mathrm{~d} 3}$ & $4.67 \pm 0.56^{\mathrm{a} 3 \mathrm{~d} 2}$ \\
\hline $\mathrm{NO} 0.2 \% \mathrm{w} / \mathrm{v}$ & $228.00 \pm 2.08^{\mathrm{a} 3}$ & $195.33 \pm 2.28^{\mathrm{a} 3}$ & $147.67 \pm 2.23^{\mathrm{a} 3}$ & $87.33 \pm 1.17^{\mathrm{a} 3}$ & $40.5 \pm 1.61^{\mathrm{a} 3}$ & $2 \pm 0.93^{\mathrm{a} 3}$ & $0.00 \pm 0.00^{\mathrm{a} 3}$ \\
\hline
\end{tabular}

Data are expressed as mean \pm SEM; $n=6$; a, compared with simple ointment; b, compared with fraction $5 \%$ (w/w); c, compared with fraction $10 \%$ (w/w) ointment; d, compared with nitrofurazone $0.2 \%$ (w/v) ointment. $1, p<0.05 ; 2, p<0.01 ; 3, p<0.001$. AQF, aqueous fraction of hydromethanolic crude extract of $B$. abyssinica leaves; CHF, chloroform fraction of hydromethanolic crude extract of $B$. abyssinica leaves; HF, hexane fraction of hydromethanolic crude extract of $B$. abyssinica leaves; NO, nitrofurazone ointment.

enhanced wound contraction of hydromethanolic extract was probably because of inhibition of microbial growth. This was evidenced by previous in vitro studies of $B$. abyssinica hydromethanolic leaves extract that exhibited much higher antibacterial activity against wound infecting pathogenic bacteria, namely, Staphylococcus aureus, Escherichia coli, and Klebsiella pneumoniae [9].

Disruption of skin with burn and other injuries causes subsequent immune suppression, which favors the above explained bacteria. These bacteria and endotoxins may end up in increase proinflammatory cytokines and make the inflammatory phase longer. Prolonged inflammation also results in an increased level of matrix Metalloproteases (MMPs), which might degrade growth factors rapidly [56]. So, eradication of the colonizing organisms with hydromethanolic crude extract from wound area allows an appropriate environment for wound healing process. B. abyssinica leaves may have mitogenic activity, which reinforces fibroblast motility and cellular proliferation. This was evidenced by histopathological analysis result that showed the presence of fibroblast proliferation and collagen deposition in animal tissue of hydromethanolic crude extract ointment group treated mice. Previous in vitro studies of $B$. abyssinica leaves on Human foreskin fibroblast also showed mitogenic activity [28]. In step with these evidences, fibroblasts stimulate the assembly or synthesis of collagen. Collagen facilitates the migration of endothelial cells to create new blood vessels to strengthen granulation formation and consequently improve wound healing, which is observed as reduction in wound area. Similarly, fibroblasts rapidly show the activated phenotype of myofibroblast, which attributes higher cellular contractility that promotes the faster closure of the wound $[43,57]$.

The other reason for enhanced wound contraction effect is the antioxidant activity. This is often evidenced by in vitro antioxidant activity of hydromethanolic extract of B. abyssinica leaves [31, 43].

Mainly, burns manifest into systemic problems like hypermetabolism. The hypermetabolic cascade seems to involve: glucose metabolism with insulin resistance (IR) and hyperglycemia. High glucose is additionally increased due to production of free radicals and decreased levels of antioxidants. High glucose level affects wound healing by delaying proliferation of cells and reduce the assembly of collagen [58]. Hence, the use of antioxidants and antidiabetic may have a positive effect on the return of skin tissue damage and other burn wound complications. On the other hand, the typical period of epithelization for excision wound model was significantly reduced from negative control (19.5), 5\%w/ $\mathrm{w}$ hydromethanolic crude extract ointment (15.83), to $10 \%$ hydromethanolic crude extract ointment (14) days. Likewise, epithelization period of burn wound model was reduced significantly with $10 \% \mathrm{w} / \mathrm{w}$ hydromethanolic crude extract ointment from 23 days in negative control group to 18 days.

Epithelialization may be a process of covering defect on the epithelial surface during the proliferative innovate, in which keratinocytes undergo a series of migration, proliferation, and differentiation. The reduced period of epithelialization obtained by the hydromethanolic crude extract ointments is due to rapid wound contraction, as contraction shortens the space for migrating keratinocytes decreases $[47,59]$. The opposite could even be due to the enhancement of collagen deposition by the hydromethanolic crude extract that facilitated proliferation, migration, and increased viability of epithelial cells [60], which is supported by histopathological analysis result.

Further wound healing activity of the hydromethanolic crude extract was evidenced by increasing durability in incision wounds. The lastingness of both $5 \% \mathrm{w} / \mathrm{w}$ and $10 \% \mathrm{w} /$ $\mathrm{w}$ hydromethanolic crude extract ointment treated groups was highly significant $(p<0.001)$ as compared with simple ointment treated and untreated groups. Tensile strength indicates what proportion of the repaired tissue resists tensile under tension and can indicate the standard of repaired tissue and enhanced collagen maturation by increased cross-linking [49]. The mitogenic activity and fibroblast proliferation could even possibly increase enduringness [28]. Fibroblasts produce large quantities of collagen, which forms the foremost constituent of the extracellular wound matrix and which is ultimately accountable for making lastingness, which sticks the wound edges together at the repaired site [61].

The other could even be due to the presence of secondary metabolites like saponins and flavonoids that also are responsible for enhancement of collagen maturation, which provides strength and integrity to the wound matrix $[9,61]$. 


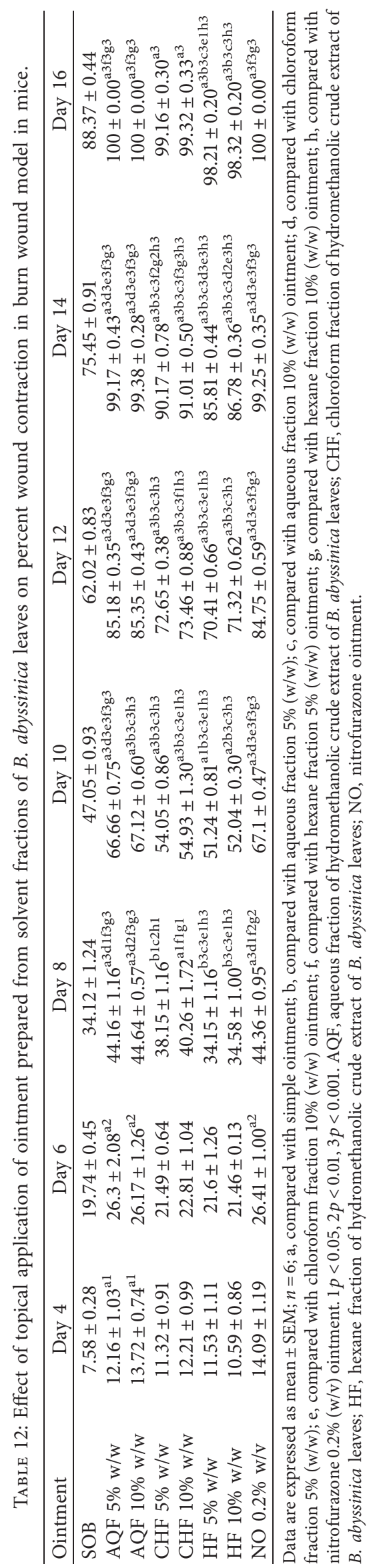


TABLE 13: Effect of topical application of ointment prepared from solvent fractions of $80 \%$ hydromethanolic leaf crude extract of B. abyssinica on period of epithelization on excision wound model in mice.

\begin{tabular}{lcc}
\hline Treatment & Epithelization period in days & Percentage reduction in period epithelization \\
\hline Simple ointment & $18.67 \pm 0.33$ & 0.00 \\
Aqueous fraction 5\% (w/w) ointment & $13.67 \pm 0.21^{\operatorname{adefg}(3)}$ & 26.78 \\
Aqueous fraction 10\% (w/w) ointment & $13.50 \pm 0.34^{\operatorname{adefg}(3)}$ & 27.69 \\
Chloroform fraction 5\% (w/w) ointment & $15.83 \pm 0.40^{\operatorname{abch}(3) \mathrm{fg}(1)}$ & 15.21 \\
Chloroform fraction 10\% (w/w) ointment & $15.67 \pm 0.33^{\mathrm{abch}(3) \mathrm{f} 2 \mathrm{~g} 1}$ & 16.07 \\
Hexane fraction 5\% (w/w) ointment & $17.33 \pm 0.21^{\mathrm{ad}(1) \mathrm{bch}(3) \mathrm{e} 2}$ & 7.18 \\
Hexane fraction 10\% (w/w) ointment & $17.17 \pm 0.17^{\mathrm{ade}(1) \mathrm{bch}(3)}$ & 8.03 \\
Nitrofurazone 0.2\% (w/v) ointment & $13.50 \pm 0.22^{\mathrm{adefg}(3)}$ & 27.69 \\
\hline
\end{tabular}

Data are expressed as mean \pm SEM; $n=6$; a, compared with simple ointment; b, compared with $5 \%$ aqueous fraction; c, compared with $10 \%$ aqueous fraction; d, compared with $5 \%$ chloroform fraction; e, compared with $10 \%$ chloroform fraction; f, compared with $5 \%$ hexane fraction; g, compared with $10 \%$ hexane fraction; h, compared with nitrofurazone $0.2 \%$ ointment; $1, p<0.05 ; 2, p<0.01 ; 3, p<0.001$.

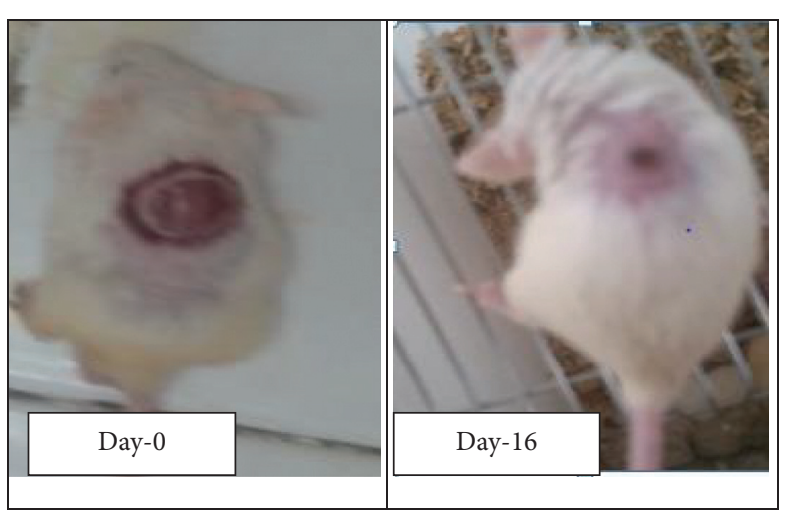

(a)

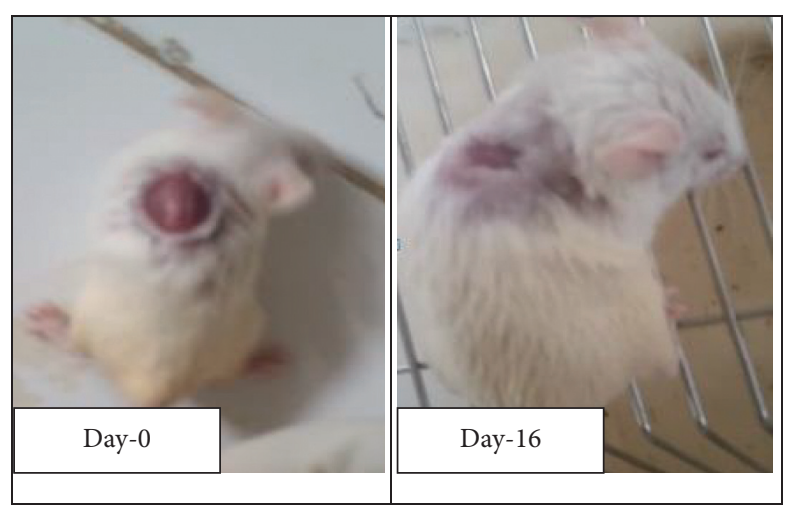

(c)

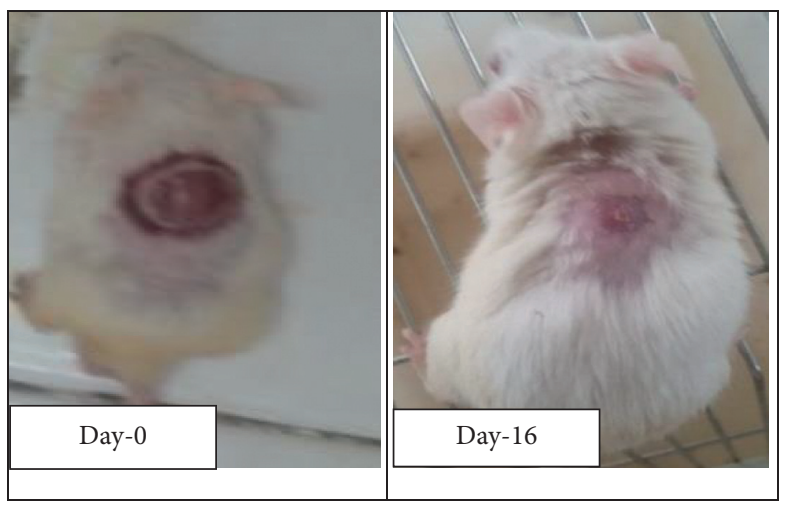

(e)

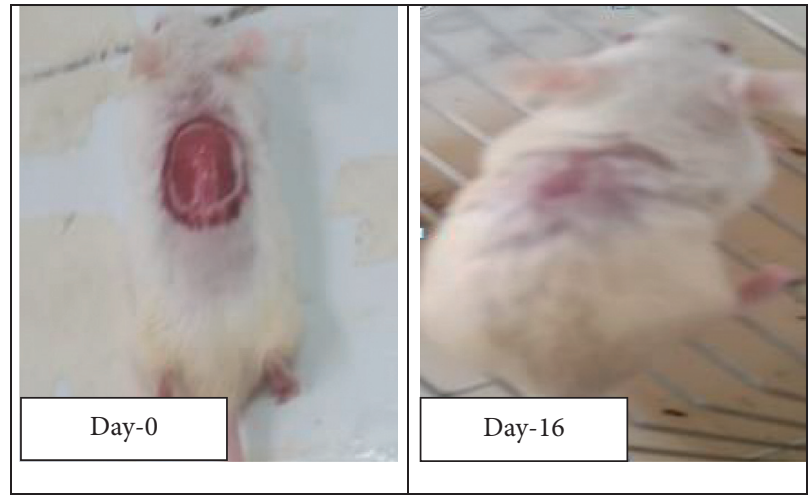

(b)

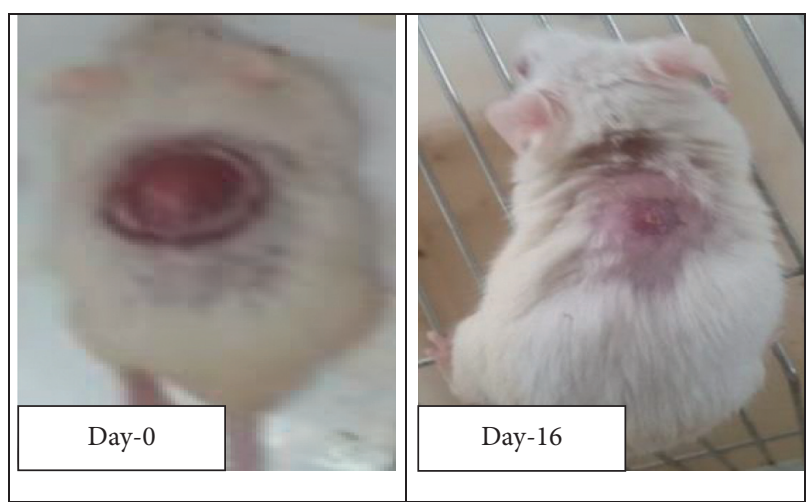

(d)
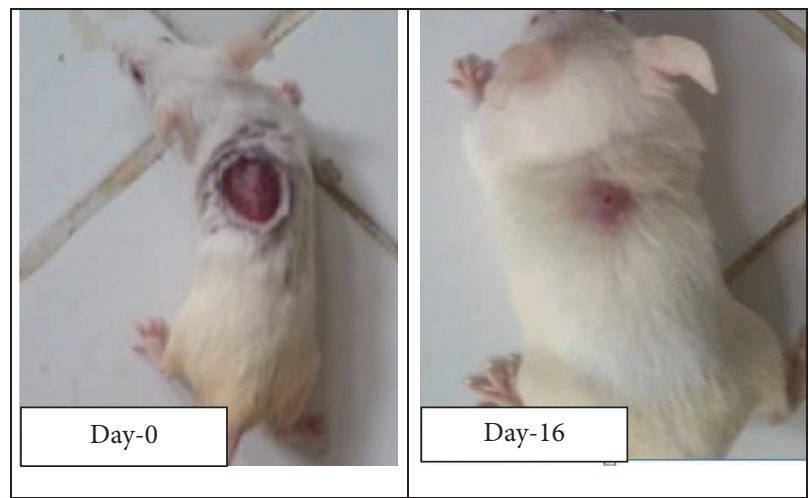

(f)

Figure 10: Continued. 


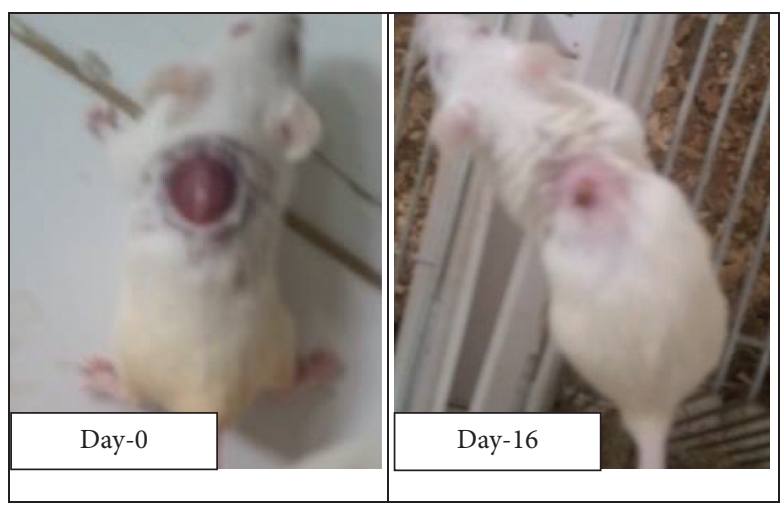

(g)

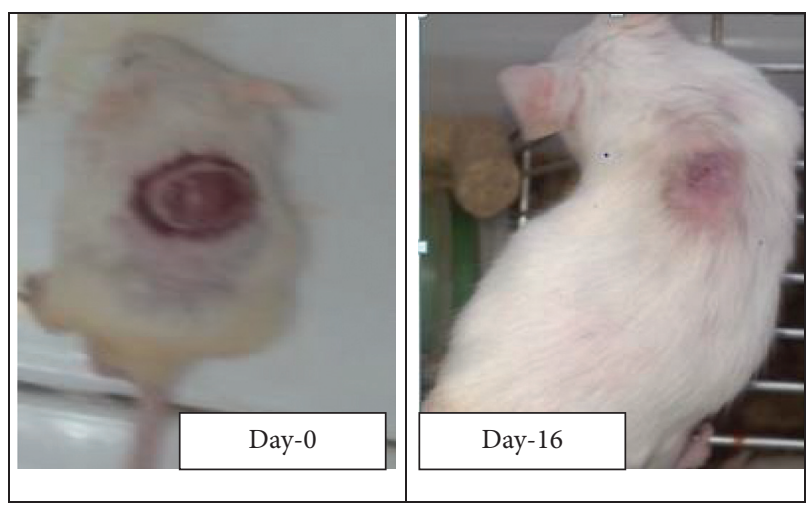

(h)

Figure 10: Photographs of excision wound model on day- 0 and treated with solvent fractions of $B$. abyssinica leaves at 16 th day post treatment $(\mathrm{AF}=$ aqueous fraction, $\mathrm{CF}=$ chloroform fraction, $\mathrm{HF}=$ hexane fraction). (a) Mice treated with simple ointment. (b) Mice treated with AF of B. abyssinica $5 \% \mathrm{w} / \mathrm{w}$ ointment. (c) Mice treated with AF of B. abyssinica $10 \% \mathrm{w} / \mathrm{w}$ ointment. (d) Mice treated with CF of B. abyssinica $5 \% \mathrm{w} / \mathrm{w}$ ointment. (e) Mice treated with CF of B. abyssinica $10 \% \mathrm{w} / \mathrm{w}$ ointment. (f) Mice treated with $\mathrm{HF}$ of $B$. abyssinica $5 \% \mathrm{w} / \mathrm{w}$ ointment. Mice treated with AF of B. abyssinica $10 \%$ w/w ointment. (h) Mice treated with nitrofurazone $0.2 \%$ w $/ \mathrm{v}$ ointment.

This can be often supported by the previous phytochemical screening and histopathological analysis.

Hydromethanolic crude extract was fractionated with different solvents like hexane, chloroform, and water to identify which fraction of the plant extract was accountable for wound healing. The fractionation result showed that the best yield obtained from the aqueous fraction is additionally due to high concentration of polar compounds in leaves of B. abyssinica and was better dissolved in water. A previous study on the leaf part also demonstrated a more robust yield using aqueous solvent $[40,43]$. In excision wound model, all three solvent fractions ointment preparations showed significant wound contraction as compared with negative control with different degrees. However, higher wound contraction was observed in aqueous fraction $(10 \% \mathrm{w} / \mathrm{w}$ and $5 \% \mathrm{w} / \mathrm{w}$ ) ointment preparation followed by chloroform fraction ointment.

The finding showed that mice treated with $10 \% \mathrm{w} / \mathrm{w}$ (aqueous, chloroform, and hexane) fraction ointment showed significant $(p<0.01)$ wound contraction starting from (2nd, 4th, and 12th postwounding day onwards, respectively) as compared with negative control. Wound contractions observed in $10 \%$ and $5 \% \mathrm{w} / \mathrm{w}$ aqueous fraction ointment treated mice were enhanced as compared with chloroform and hexane fraction ointment treated groups for several postwounding days and slightly beyond reference drug treated mice. On the other hand, the number of epithelization for excision wound model was significantly reduced from negative control (18.7) to aqueous fraction ointment $10 \% \mathrm{w} / \mathrm{w}$ and nitrofurazone $0.2 \% \mathrm{w} / \mathrm{v}$ ointment (13.5) days. Better wound healing effect of aqueous fraction could result from antibacterial, antioxidant, and antifungal activity. This will be supported by previous in vitro studies of aqueous fraction of $B$. abyssinica that had bactericidal activity against all multiresistant strains of Staphylococcus aureus, and aqueous fraction possesses an antifungal activity [9]. Infection can seriously delay healing process by causing poor quality animal tissue formation, reduced durability of animal tissue, and impaired epithelization [36]. Therefore antibacterial and antifungal activity of the plant is additionally important to spice up wound healing by preventing infection.

It may even ensue the antioxidant activity. This effect is supported by previous in vitro studies of aqueous fraction showed highest free radical-scavenging ability by using DPPH [43]. Antioxidants could be a defense mechanism through which an individual's body is getting protected against oxidative damage of free radicals. Free radicals are produced in response to cutaneous injury. They delay the healing process by causing damage to cellular membranes, DNA, proteins, lipids, and other cellular structure and function [52].

The antioxidant effect might enable the leaves of the experimental plant inhibit lipid peroxidation, prevent cell damage, and increase collagen fibrillary survival of the healing wound that would produce rapid wound contraction and shorter period of epithelization [62]. In addition, the higher wound healing effect of the aqueous fraction could even be related with the discharge profile from simple ointment. The efficacy and delivery of a drug are laid low with the formulation vehicle. Polar ingredient of the drug is additionally released better from the nonpolar base and contrariwise, so that most polar active ingredients within the aqueous fraction are additionally better released from nonpolar base [45].

Moderate wound contraction and moderate reduction in epithelization period of chloroform fraction could even be due to moderate antibacterial effect of the plant and fewer phytochemical content than hydromethanolic crude extracts. This is often evidenced by in vitro antibacterial studies against wound infecting bacteria. On this study, chloroform fraction had good effect in Escherichia coli only but moderate effect for the above explained bacteria. Previous phytochemical studies of chloroform fraction of the plant showed the presence of few phytochemicals namely flavonoids, glycosides, and alkaloid only as compared with 
hydromethanolic extract that contains 11 phytochemicals that are important for wound healing. The late and fewer wound healing effect of hexane fraction from chloroform and water fractions could even be due to difference in the proportion (concentration) of the active components liable for anti-inflammatory activity resulting from the difference in solubility. This indicated firmer wound healing phytochemical quantitatively and/or qualitatively resides within semipolar and polar solvents.

In the above three wound healing models, higher $(10 \%$ $\mathrm{w} / \mathrm{w}$ ) ointment preparation showed better effect than low $(5 \% \mathrm{w} / \mathrm{w})$ ointment preparation of the plant. This might result in increasing the dose of the plant and increase the proportion of the chemical ingredients with pharmaceutical value in plant [63].

Wound healing effect of $B$. abyssinica leaves hydromethanolic crude extract and solvent fractions could even be because of its phytoconstituents like flavonoids, saponin, tannin, triterpenoids, alkaloid, phytosterols, glycosides, phenols, steroids, anthraquinones, coumarin individual, or additive effects [64]. This is often supported by plants, which had wound healing effect in vivo and had these phytochemicals. Phytochemicals contribute to the observed wound healing effects with different mechanisms.

Flavonoids can reduce highly oxidizing free radicals by forming less reactive flavonoid radicals. As a result, they are able to prevent lipid peroxidation, increase collagen synthesis, promote the cross-linking of collagen, shorten the inflammation period, and render resistance against infections, which are important factors in enhancing the wound healing process $[9,61]$. Phenolic compounds also exhibit a considerable radical-scavenging (antioxidant) activity [9]. Saponins have antioxidant, hemolytic activities precipitate proteins and aggregate red blood cells and wont to treat wounds and stop bleeding from injured site [33-35]. Saponins enhance wound contraction and bringing collagen deposition and promote angiogenesis during wound repair [45-47]. Therefore, B. abyssinica is employed to treat wounds in traditional medicine because of the presence of saponins. Tannins are reported as having astringent activities, which helps quicken wound healing and treat inflammations, promote wound contraction, improve healing rate, and promote healing of infectious wounds [7]. Triterpenoids are also known to stimulate the wound healing process mainly thanks to their astringent and antimicrobial property, which seems to be chargeable for wound contraction and increased rate of epithelialization. Alkaloids are observed to stimulate early phases of wound healing with the potential to stimulate fibroblasts 56. Phytosterols are credited for wound healing due to free radical-scavenging and antioxidant activity, which are known to decrease lipid peroxidation, thereby reducing cell necrosis and improving vascularity. Glycosides possess antioxidant, antimicrobial, and anti-inflammatory effects $[47,65]$. Steroids are antimicrobial, analgesic, anti-inflammatory, and anthraquinones modulate inflammation by partially inhibiting cyclooxygenase [66].

\section{Conclusion}

The hydromethanolic crude extract and solvent fractions of B. abyssinica leaves showed wound healing effects on tested parameters in mice. Aqueous fractions possess higher wound healing activity than chloroform and hexane fractions. This indicated that phytochemicals present in the leaves were soluble in the solvents used for extraction furthermore as for fractionation. This upholds its folkloric use of leaves of B. abyssinica and might be considered as a possible source to develop new wound healing agent.

\section{Data Availability}

The datasets used and/or analyzed during the current study are available from the corresponding author and will be submitted when requested.

\section{Ethical Approval}

The experimental animals were handled and cared in the experimental procedures in step with the local ethical and internationally accepted laboratory animal use, care, and welfare guidelines like Basel declaration, ICLAS Ethical Guideline, and EU directive on the protection of animals used for scientific purposes [38, 39]. And, therefore, the ethical clearance was requested and obtained from School of Pharmacy ethics review committee, University of Gondar, under Reference number of SoP4/153/12. The research was performed as per the agreement.

\section{Conflicts of Interest}

The authors declare that they have no conflicts of interest to disclose.

\section{Authors' Contributions}

All the authors made substantial contributions to conception and design, acquisition of data, or analysis and interpretation of data; took part in drafting the article or revising it critically for important intellectual content; agreed to submit to the current journal; gave final approval of the version to be published; and agreed to be accountable for all aspects of the work.

\section{Acknowledgments}

The authors are extremely grateful to the University of Gondar for the approval of ethical clearance and support of laboratory facility and authentication of experimental plant. 


\section{References}

[1] R. Shalu, G. S. Amanjot, K. Kapil, and K. Sukhbir, "Wound healing potential of medicinal plants with their screening models: a comprehensive review," Journal of Drug Delivery \& Therapeutics, vol. 6, no. 1, pp. 56-66, 2016.

[2] K. Järbrink, G. Ni, H. Sönnergren et al., "Prevalence and incidence of chronic wounds and related complications: a protocol for a systematic review," Systematic Reviews, vol. 5, no. 1, p. 152, 2016.

[3] S. Sarabahi, "Recent advances in topical wound care," Indian Journal of Plastic Surgery: Official Publication of the Association of Plastic Surgeons of India, vol. 45, no. 2, pp. 379-87, 2012.

[4] H. Yuan, Q. Ma, L. Ye, and G. Piao, "The traditional medicine and modern medicine from natural products," Molecules, vol. 21, no. 5, p. 559, 2016.

[5] S. M. Wassie, L. L. Aragie, B. W. Taye, and L. B. Mekonnen, "Knowledge, attitude, and utilization of traditional medicine among the communities of Merawi town, Northwest Ethiopia: a cross-sectional study," Evidence-Based Complementary and Alternative Medicine, vol. 2015, Article ID 138073, 2015.

[6] T. Efferth and H. J. Greten, "Traditional medicine with plants-present and past," Medicinal \& Aromatic Plants, vol. 3, no. 3, pp. 1-3, 2014.

[7] O. Oyebode, N.-B. Kandala, P. J. Chilton, and R. J. Lilford, "Use of traditional medicine in middle-income countries: a WHO-SAGE study," Health Policy and Planning, vol. 31, no. 8, pp. 984-991, 2016.

[8] A. Marume, G. Matope, S. Katsande et al., "Wound healing properties of selected plants used in ethnoveterinary medicine," Frontiers in Pharmacology, vol. 8, p. 544, 2017.

[9] M. Anza, F. Worku, S. Libsu, F. Mamo, and M. Endale, "Phytochemical screening and antibacterial activity of leaves extract of Bersama abyssinica," Journal of Advances in Zoology and Botany, vol. 3, no. 2, pp. 1-5, 2015.

[10] Y. Limenih, S. Umer, and M. Wolde-Mariam, "Ethnobotanical study on traditional medicinal plants in Dega Damot woreda, Amhara region, north Ethiopia," International Journal of Research in Pharmacy and Chemistry, vol. 5, no. 2, pp. 258-273, 2015.

[11] S. W. Yohannis, Z. Asfaw, and E. Kelbessa, "Ethnobotanical study of medicinal plants used by local people in menz gera midir district, north shewa zone, amhara regional state, Ethiopia," Journal of Medicinal Plants Research, vol. 12, no. 21, pp. 296-314, 2018.

[12] M. Wubetu, T. Abula, and G. Dejenu, "Ethnopharmacologic survey of medicinal plants used to treat human diseases by traditional medical practitioners in Dega Damot district, Amhara, Northwestern Ethiopia," BMC Research Notes, vol. 10, no. 1, p. 157, 2017.

[13] G. Chekole, Z. Asfaw, and E. Kelbessa, "Ethnobotanical study of medicinal plants in the environs of Tara-gedam and Amba remnant forests of Libo Kemkem District, northwest Ethiopia," Journal of Ethnobiology and Ethnomedicine, vol. 11, no. 1, p. 4, 2015.

[14] Z. Birhanu, A. Endale, and Z. Shewamene, "An ethnomedicinal investigation of plants used by traditional healers of Gondar town, North-Western Ethiopia," Journal of Medicinal Plants Studies, vol. 3, no. 2, pp. 36-43, 2015.

[15] E. Lulekal, Z. Asfaw, E. Kelbessa, and P. Van Damme, "Ethnomedicinal study of plants used for human ailments in Ankober district, north Shewa zone, Amhara region,
Ethiopia," Journal of Ethnobiology and Ethnomedicine, vol. 9, no. 1, p. 63, 2013.

[16] H. Atnafu, T. Awas, S. Alemu, and S. Wube, "Ethnobotanical study of medicinal plants in selale mountain ridges, North Shoa, Ethiopia," International Journal of Biodiversity, vol. 2, no. 6, pp. 567-577, 2018.

[17] M. Mirutse Giday, Z. Zemede Asfaw, and Z. Zerihun Woldu, "Medicinal plants of the Meinit ethnic group of Ethiopia: an ethnobotanical study," Journal of Ethnopharmacology, vol. 124, no. 3, pp. 513-521, 2009.

[18] M. Kebebew, "Diversity, knowledge and use of medicinal plants in abay Chomen district, horo guduru wollega zone, oromia region of Ethiopia," Journal of Medicinal Plants Research, vol. 11, no. 31, pp. 480-500, 2017.

[19] B. Kidane, T. van Andel, L. van der Maesen, and Z. Asfaw, "Use and management of traditional medicinal plants by Maale and Ari ethnic communities in southern Ethiopia," Journal of Ethnobiology and Ethnomedicine, vol. 10, no. 1, p. 46, 2014.

[20] G. Bekele and P. R. Reddy, "Ethnobotanical study of medicinal plants used to treat human ailments by Guji Oromo tribes in Abaya District, Borana, Oromia, Ethiopia," Universal Journal of Plant Science, vol. 3, no. 1, p. 4, 2015.

[21] N. Tuasha, B. Petros, and Z. Asfaw, "Medicinal plants used by traditional healers to treat malignancies and other human ailments in Dalle District, Sidama Zone, Ethiopia," Journal of Ethnobiology and Ethnomedicine, vol. 14, no. 1, p. 15, 2018.

[22] B. Abera, "Medicinal plants used in traditional medicine by Oromo people, Ghimbi District, Southwest Ethiopia," Journal of Ethnobiology and Ethnomedicine, vol. 10, no. 1, pp. 40-45, 2014.

[23] N. Wabe, M. Mohammed, and N. Raju, "An ethnobotanical survey of medicinal plants in the Southeast Ethiopia used in traditional medicine," Spatula DD-Peer Reviewed Journal on Complementary Medicine and Drug Discovery, vol. 1, no. 3, pp. 153-158, 2011.

[24] B. Abera, "Medicinal plants used in traditional medicine in Jimma Zone, Southwest Ethiopia," Ethiopian Journal of Health Sciences, vol. 13, no. 2, 2003.

[25] Y. Fenetahun and G. Eshetu, "A review on ethnobotanical studies of medicinal plants use by agro-pastoral communities in, Ethiopia," Journal of Medicinal Plants, vol. 5, no. 1, pp. 33-44, 2017.

[26] M. Mengistu, D. Kebede, D. Atomsa, A. Abebe, and D. Alemnie, "Status and utilization of medicinal and aromatic plants in Eastern Hararghe, Ethiopia," Cogent Food \& Agriculture, vol. 5, no. 1, Article ID 1701349, 2019.

[27] A. Teka, J. Rondevaldova, Z. Asfaw et al., "In vitro antimicrobial activity of plants used in traditional medicine in Gurage and Silti Zones, south central Ethiopia," BMC Complementary and Alternative Medicine, vol. 15, no. 1, p. 286, 2015.

[28] K. BENE and D. CAMARA, "Optimizing mitogenic potential of HFF cells by ethanol extracts of leaves of Bersama abyssinica fresen.(Melianthaceae) and harrisonia abyssinica oliv.(Simaroubaceae)," International Journal of Science and Research (IJSR), vol. 5, no. 1, 2016.

[29] N. Z. Mwambela, M. Chacha, and F. Shahada, "Investigation of antimycobacterial and cytotoxicity activity of Bersama abyssinica Fresen extracts from Tanzania," International Journal of Life Sciences Biotechnology and Pharma Research, vol. 3, no. 4, p. 23, 2014.

[30] T. N. Ong'era, O. Amuka, A. K. Machocho, and N. K. Gikonyo, "Antimicrobial activities screening of some 
phytochemicals from the stem bark extracts of Bersama abyssinica (Fresen)," Medicinal Plants-International Journal of Phytomedicines and Related Industries, vol. 9, no. 1, pp. 20-28, 2017.

[31] K. Asres, S. Gibbons, and F. Bucar, "Radical scavenging compounds from Ethiopian medicinal plants," Ethiopian Pharmaceutical Journal, vol. 24, pp. 23-30, 2006.

[32] K. Bene, A. Kra, K. Konan, and G. Zirihi, "Bersama abyssinica fresen. (Melianthaceae): antifungal activity on aflatoxin B1producing mold," British Journal of Pharmaceutical Research, vol. 15, no. 1, pp. 1-6, 2017.

[33] O. U. Christina, D. Baxter-Grillo, N. Helen, and I. P. Tracy, "Phytochemical, proximate and elemental constituents of Aspilia africana (Wild sunflower) flowers," Journal of Medicinal Plants, vol. 5, no. 4, pp. 22-27, 2017.

[34] M. U. Ekaiko, A. G. Arinze, C. U. Iwe, and E. I. Asiegbu, "Phytochemical constituents and antimicrobial potency of Aspilia africana," International Journal of Life Sciences Research, vol. 4, no. 1, pp. 9-14, 2016.

[35] L. Razika, A. C. Thanina, C. M. Nadjiba, B. Narimen, D. M. Mahdi, and A. Karim, "Antioxidant and wound healing potential of saponins extracted from the leaves of Algerian Urtica dioica L," Pakistan Journal of Pharmaceutical Sciences, vol. 30, 2017.

[36] Y.-S. Kim, I.-H. Cho, M.-J. Jeong et al., “Therapeutic effect of total ginseng saponin on skin wound healing," Journal of Ginseng Research, vol. 35, no. 3, pp. 360-367, 2011.

[37] Y. Kimura, M. Sumiyoshi, K. Kawahira, and M. Sakanaka, "Effects of ginseng saponins isolated from Red Ginseng roots on burn wound healing in mice," British Journal of Pharmacology, vol. 148, no. 6, pp. 860-870, 2006.

[38] National Research Council, Guide for the Care and Use of Laboratory Animals, National Academies Press, Ottawa, Canada, 2010.

[39] B. J. Mohr, F. A. Fakoya, J. Hau, O. Souilem, and L. Anestidou, "The governance of animal care and use for scientific purposes in Africa and the Middle East," ILAR Journal, vol. 57, no. 3, pp. 333-346, 2016.

[40] A. A. Alehegn, J. S. Yesuf, and E. M. Birru, "Antimalarial activity of crude extract and solvent fractions of the leaves of Bersama abyssinica fresen. (Melianthaceae) against Plasmodium berghei infection in Swiss albino mice," Evidence-based Complementary and Alternative Medicine, vol. 2020, Article ID 9467359, 2020.

[41] M. A. Alemayehu, M. Abdelwuhab, and D. A. Gelayee, "Invivo anti-malarial activity of crude extract and solvent fractions of the roots of Clematis simensis Fresen.(Ranunculaceae) in Plasmodium berghei infected mice," IOSR Journal of Pharmacy and Biological Sciences, vol. 14, no. 5, pp. 52-62, 2020.

[42] B. Pharmacopoeia, Department of Health and Social Security Scottish Home and Health Department, p. 713, Office of the British Pharmacopoeia Commission, London, UK, 1988.

[43] Z. D. Kifle and E. F. Enyew, "Evaluation of in vivo antidiabetic, in vitro $\alpha$-amylase inhibitory, and in vitro antioxidant activity of leaves crude extract and solvent fractions of Bersama abyssinica fresen (melianthaceae)," Journal of EvidenceBased Integrative Medicine, vol. 25, 2020.

[44] Chemicals. OGftto. Acute Dermal Toxicity: Fixed Dose Procedure. 2017, http://www.oecd.org/termsandconditions/.

[45] W. Demilew, G. M. Adinew, and S. Asrade, "Evaluation of the wound healing activity of the crude extract of leaves of Acanthus polystachyus Delile (Acanthaceae)," Evidence-based
Complementary and Alternative Medicine, vol. 2018, Article ID 2047896, 2018.

[46] L. Gebremeskel, D. Bhoumik, G. G. Sibhat, and K. B. Tuem, "In vivo wound healing and anti-inflammatory activities of leaf latex of aloe megalacantha baker (Xanthorrhoeaceae)," Evidence-based Complementary and Alternative Medicine, vol. 2018, Article ID 5037912, 2018.

[47] T. F. Belachew, S. Asrade, M. Geta, and E. Fentahun, "In Vivo evaluation of wound healing and anti-inflammatory activity of $80 \%$ methanol crude flower extract of hagenia abyssinica (Bruce) JF gmel in mice," Evidence-Based Complementary and Alternative Medicine, vol. 2020, Article ID 9645792, 2020.

[48] S. Gargiulo, A. Greco, M. Gramanzini et al., "Mice anesthesia, analgesia, and care, part I: anesthetic considerations in preclinical research," ILAR Journal, vol. 53, no. 1, pp. E55-E69, 2012.

[49] K. Beshir, W. Shibeshi, A. Ejigu, and E. Engidawork, "In-vivo wound healing activity of $70 \%$ ethanol leaf extract of Beciumgrandiflorum Lam. (Lamiaceae) in mice," Ethiopian Pharmarmaceutical Journal, vol. 32, pp. 117-130, 2016.

[50] E. Mulisa, K. Asres, and E. Engidawork, "Evaluation of wound healing and anti-inflammatory activity of the rhizomes of Rumex abyssinicus J. (Polygonaceae) in mice," BMC Complementary and Alternative Medicine, vol. 15, no. 1, p. 341, 2015.

[51] I. K. R. Agra, L. L. S. Pires, P. S. M. Carvalho, E. A. Silva-Filho, S. Smaniotto, and E. Barreto, "Evaluation of wound healing and antimicrobial properties of aqueous extract from Bowdichia virgilioides stem barks in mice," Anais da Academia Brasileira de Ciências, vol. 85, no. 3, pp. 945-954, 2013.

[52] V. K. A. N. K. Kumar, "Animal models for the evaluation of wound healing activity," International Bulletin of Drug Research, vol. 3, no. 5, pp. 93-107, 2013.

[53] J. R. Rex, N. M. Muthukumar, and P. M. Selvakumar, "Phytochemicals as a potential source for antimicrobial, antioxidant and wound healing-a review," MOJ Bioorganic \& Organic Chemistry, vol. 2, no. 2, pp. 61-70, 2018.

[54] N. N. Azwanida, "A review on the extraction methods use in medicinal plants, principle, strength and limitation," Med Aromat Plants, vol. 4, no. 196, pp. 2167-0412, 2015.

[55] K. S. Yadav, N. P. Yadav, B. Rawat, V. K. Rai, K. Shanker, and C. Venkateswara Rao, "An assessment of wound healing potential of Argyreia speciosa leaves," The Scientific World Journal, vol. 2014, Article ID 406921, 2014.

[56] S. Porter, "The role of the fibroblast in wound contraction and healing," Wounds UK, vol. 3, no. 1, p. 33, 2007.

[57] A. Said, F. Wahid, K. Bashir et al., "Sauromatum guttatum extract promotes wound healing and tissue regeneration in a burn mouse model via up-regulation of growth factors," Pharmaceutical Biology, vol. 57, no. 1, pp. 736-743, 2019.

[58] Y. D. Boakye, C. Agyare, G. P. Ayande, N. Titiloye, E. A. Asiamah, and K. O. Danquah, "Assessment of woundhealing properties of medicinal plants: the case of Phyllanthus muellerianus," Frontiers in Pharmacology, vol. 9, p. 945, 2018.

[59] Y. Shao, M. Dang, Y. Lin, and F. Xue, "Evaluation of wound healing activity of plumbagin in diabetic rats," Life Sciences, vol. 231, Article ID 116422, 2019.

[60] S. T. Tan and R. Dosan, "Lessons from epithelialization: the reason behind moist wound environment," The Open Dermatology Journal, vol. 13, no. 1, 2019.

[61] S. Udegbunam, R. Kene, S. Anika, R. Udegbunam, T. Nnaji, and M. Anyanwu, "Evaluation of wound healing potential of methanolic Crinum jagus bulb extract," Journal of Intercultural Ethnopharmacology, vol. 4, no. 3, p. 194, 2015. 
[62] G. Ayal, A. Belay, and W. Kahaliw, "Evaluation of wound healing and anti-inflammatory activity of the leaves of Calpurnia aurea (Ait.) Benth (fabaceae) in mice," Wound Medicine, vol. 25, no. 1, Article ID 100151, 2019.

[63] R. Komakech, M. G. Matsabisa, and Y. Kang, "The wound healing potential of aspilia africana (pers.) C. D. Adams (asteraceae)," Evidence-based Complementary and Alternative Medicine, vol. 2019, Article ID 7957860, 2019.

[64] V. Garg and S. Paliwal, "Wound-healing activity of ethanolic and aqueous extracts of Ficus benghalensis," Journal of Advanced Pharmaceutical Technology \& Research, vol. 2, no. 2, p. 110, 2011.

[65] R. A. Nugroho, D. Utami, R. Aryani, F. M. Nur, Y. Sari, and H. Manurung, Eds., Journal of Physics: Conference Series, vol. 1277, 2019.

[66] C. Egbuna and J. Ifemeje, "Comparative studies on the phytochemical properties of five Nigerian medicinal plants," Journal of Advances in Medical and Pharmaceutical Sciences, vol. 6, no. 2, pp. 1-12, 2016. 